\begin{tabular}{|c|c|}
\hline Title & A new tectono-magmatic model for the L ofoten $N$ esteralen Margin at the outer limit of the Iceland Plume influence \\
\hline Author(s) & Breivik, A sbjorn Johan; Faleide, Jan Inge; Mjelde, Rolf; Flueh, Ernst R.; Murai, Y oshio \\
\hline Citation & $\begin{array}{l}\text { Tectonophysics, 718, 25-44 } \\
\text { https://doi.org/10.1016/.tecto.2017.07.002 }\end{array}$ \\
\hline Issue Date & $2017-10-30$ \\
\hline Doc URL & http:/hdl .handle.net/2115/74897 \\
\hline Rights & $\begin{array}{l}\text { () 2017. This manuscript version is made available under the CC-BY-NC-ND } 4.0 \text { license } \\
\mathrm{http}: / / \text { reativecommons.org/icenses/by-nc-nd/4.0/ }\end{array}$ \\
\hline Rights(URL) & http://creativecommons.org/icenses/by-nc-nd/4.0/ \\
\hline Type & article (author version) \\
\hline File Information & Tectonophysics718 25-44.pdf \\
\hline
\end{tabular}

Instructions for use 
Corresponding address: Centre for Earth Evolution and Dynamics (CEED), Department of Geosciences, University of Oslo, PO Box 1028, N-0315 Oslo, Norway

\title{
A new tectono-magmatic model for the Lofoten/Vesterålen Margin at the outer limit of the Iceland Plume influence
}

\author{
Asbjørn Johan Breivik ${ }^{\mathrm{a}}$, Jan Inge Faleide ${ }^{\mathrm{a}}$, Rolf Mjelde ${ }^{\mathrm{b}}$, Ernst R. Flueh $^{\mathrm{c}}$, Yoshio Murai ${ }^{\mathrm{d}}$ \\ ${ }^{a}$ Centre for Earth Evolution and Dynamics (CEED), Department of Geosciences, University of Oslo, Norway \\ ${ }^{b}$ Department of Earth Science, University of Bergen, Norway \\ ${ }^{c}$ IFM-Geomar, Leibniz-Institute for Marine Sciences, Kiel, Germany \\ ${ }^{d}$ Institute of Seismology and Volcanology, Hokkaido University, Sapporo, Japan
}

\begin{abstract}
The Early Eocene continental breakup was magma-rich and formed part of the North Atlantic Igneous Province. Extrusive and intrusive magmatism was abundant on the continental side, and a thick oceanic crust was produced up to a few m.y. after breakup. However, the extensive magmatism at the Vøring Plateau off mid-Norway died down rapidly northeastwards towards the Lofoten/Vesterålen Margin. In 2003 an Ocean Bottom Seismometer profile was collected from mainland Norway, across Lofoten, and into the deep ocean. Forward/inverse velocity modeling by raytracing reveals a continental margin transitional between magma-rich and magma-poor rifting. For the first time a distinct lower-crustal body typical for volcanic margins has been identified at this outer margin segment, up to $3.5 \mathrm{~km}$ thick and $\sim 50 \mathrm{~km}$ wide. On the other hand, expected extrusive magmatism could not be clearly identified here. Strong reflections earlier interpreted as the top of extensive lavas may at least partly represent high-velocity sediments derived from the shelf, and/or fault surfaces. Early post-breakup oceanic crust is moderately thickened $(\sim 8 \mathrm{~km})$, but is reduced to $6 \mathrm{~km}$ after $1 \mathrm{~m} . \mathrm{y}$. The adjacent continental crystalline crust is extended down to a minimum of $4.5 \mathrm{~km}$ thickness. Early plate spreading rates derived from the Norway Basin and the northern Vøring Plateau were used to calculate synthetic magnetic seafloor anomalies, and compared to our ship magnetic profile. It appears that continental breakup took place at $\sim 53.1$ Ma, $\sim 1$ m.y. later than on the Vøring Plateau, consistent with late strong crustal extension. The
\end{abstract}


low interaction between extension and magmatism indicates that mantle plume material was not present at the Lofoten Margin during initial rifting, and that the observed excess magmatism was created by late lateral transport from a nearby pool of plume material into the lithospheric rift zone at breakup time.

Key words: Ocean bottom seismometers, Large igneous provinces, Marine magnetics, Continental breakup

\section{Introduction}

Early Cenozoic continental breakup between East Greenland and Europe was in most parts 4 et al., 1987; Eldholm and Grue, 1994; Eldholm and Coffin, 2000). Pre-breakup magmatism af5 fected areas from Easternmost Canada and West Greenland to the Northeastern Europe in the Pa6 leogene (e.g., Saunders et al., 1997). The breakup-related magmatism varies considerably along the margins, to some extent as a function of the expected distance from the Iceland hotspot (e.g., Berndt et al., 2001; Holbrook et al., 2001; Voss et al., 2009; Breivik et al., 2012). Magmatic productivity falls considerably from the Faeroes Margin (White et al., 2008) to the northern part of the Møre Margin (Berndt et al., 2001; Breivik et al., 2006), before it again becomes very voluminous at the Vøring Plateau (Mjelde et al., 2005b; Breivik et al., 2009). The position of the Iceland Plume center in the past is much debated (e.g., Mihalffy et al., 2008), but most publications locate it somewhere under Greenland around breakup time. Despite this uncertainty, it appears that the distance relationship does not follow the margin in a linear fashion due to margin offsets; the Vøring Plateau may actually be slightly closer to the plume center than the northern Møre Margin (Vink, 1984; Skogseid et al., 2000; Howell et al., 2014). In Figure 1 plume positions from Lawver and Müller (1994) are plotted with a $1000 \mathrm{~km}$ radius. While the exact position with time as well as the areal influence both are uncertain, it illustrates that the Lofoten/Vesterålen Margin appears to be at the outer limit of the plume influence around breakup time.

Email addresses: a.j.breivik@geo.uio.no (Asbjørn Johan Breivik ) 
A number of publications have studied the relationship between igneous crustal thickness and average igneous lower-crustal seismic velocity for the NAIP margins (Holbrook et al., 2001; Breivik et al., 2006, 2009, 2012, 2014; White et al., 2008). Most of these show a simple, positive correlation as would be expected from magmatism driven by a finite, hot mantle reservoir, consistent with emplacement of Iceland plume material under the continental breakup zone. Only two regions show a significant departure from this; the part of the East Greenland margin close to Iceland (Holbrook et al., 2001), and the Vøring Plateau (Breivik et al., 2009, 2014). While showing the effect of elevated temperature close to Iceland, the velocity is lower than expected when compared to the amount magma produced, which Holbrook et al. (2001) interpreted to be the result of active convection driven by the Iceland plume, fluxing an excess of mantle material through the melt zone compared to passive spreading. However, this conclusion has been challenged by White and Smith (2009), who pointed out that the low velocity could result from the continentocean boundary to be located farther out. A significant fraction of continental crust would then be included in the velocity calculation and bias the results towards lower values.

Breivik et al. (2014) concluded that the first two million years of seafloor spreading at the Vøring Plateau produced thick igneous crust with lower than expected velocity. The northern Vøring Plateau has identifiable magnetic seafloor spreading anomalies within this part (Breivik et al., 2009), showing it to be oceanic. Therefore, it was suggested that a secondary process may have contributed to the earliest and most voluminous magmatic phase. One possible explanation could be that plume material ponded under the thinned lithosphere in the developing rift zone (Sleep, 1997) flowed laterally into the plate boundary region to produce excessive decompression melting during the early seafloor spreading. The observed lower-crustal velocity temporal development is similar to that predicted by models of the interaction between pre-existing lithospheric structure, plume material, and continental breakup by Armitage et al. (2010), producing two lowercrustal velocity peaks after breakup. Clearly, there are still issues around the early magmatic phase of the NAIP that needs further investigation.

Post-breakup magmatism died down rapidly north of the Vøring Plateau, as seen from older Ocean Bottom Seismometer (OBS) studies (Mjelde et al., 1992; Kodaira et al., 1995). Off the southern Lofoten islands the early post-breakup magmatism is about $60 \%$ that of the northern 
Vøring Plateau (Breivik et al., 2009). On the other hand, extensive lava flows have been reported on the outer Lofoten/Vesterålen Margin (Talwani et al., 1983; Mjelde et al., 1992, 1993; Mokhtari and Pegrum, 1992; Tsikalas et al., 2001), an interpretation that can be questioned in the light of newer data, as we will discuss below. Unlike other volcanic margin segments, little or no lowercrustal intrusions were so far identified.

In addition to the reduced magmatism, the Lofoten/Vesterålen Margin is much more extended and thinned than the outer Vøring Plateau and the Møre Margin to the south (Mjelde et al., 1992, 2001, 2005b, 2009; Kodaira et al., 1995; Breivik et al., 2006). Clearly, there is a major change in both tectonic as well as magmatic development from the Møre Margin and the Vøring Plateau to the Lofoten/Vesterålen Margin, even if there is no transform offset between them. There are a wide range of margin structures observed world-wide: The hyper-extended margin is typified by the Iberia Margin, which is characterized by large crustal extension with low strain rate, crustpenetrating detachment faults, upper-mantle serpentinization, and sparse magmatism even after continental separation (e.g., Whitmarsh et al., 2001). The typical volcanic margin, e.g., the Faeroes Margin (White et al., 2008), is characterized by less breakup-related crustal extension, extensive magmatic intrusions, lava flows, and a high magma production during the earliest seafloor spreading. Magma-compensated crustal extension may also occur during the breakup phase, creating sizable magmatic intrusive complexes in the lowermost crust (Thybo and Nielsen, 2009; Stab et al., 2016). Three main factors are believed to control the style of crustal breakup. These are lower-crustal composition, upper mantle temperature, and strain rate (Pérez-Gussinyé and Reston, 2001). We will take a closer look at how these determining factors may differ from the Vøring Plateau to the Lofoten/Vesterålen Margin, and how this can explain the rapid shift in the tectonomagmatic development from one margin segment to the next.

The profile presented here is part of a large OBS survey conducted in 2003 as part of the Euromargins program. The profile crosses the northern Lofoten islands, the shelf and outer margin, to terminate in the deep ocean (Fig. 2). Seismic land stations were also deployed in order to better constrain the continental crustal structure underneath the archipelago. Main structural elements covered comprise the Jennegga High (northern part of the Utrøst Ridge) in the west, the Ribban Basin, and the Vestfjorden Basin located between Lofoten and the Norwegian mainland in the 
east. Based on the results of this study, a new tectono-magmatic development model for the Lofoten/Vesterålen Margin is proposed, where not only the amount of plume material present is important, but also the timing of its arrival. Alternative, non-magmatic interpretations for the observations that lead some authors to propose extensive landward lava flows are also explored.

\section{Data Acquisition and Processing}

The survey was conducted during the summer of 2003 by the R/V Håkon Mosby, in cooperation between the Department of Geosciences, University of Oslo, the Department of Earth Science, University of Bergen, both Norway, GEOMAR, Kiel, Germany, and the Institute for Seismology and Volcanology (ISV), Hokkaido University, Sapporo, Japan. The seismic signal was generated by four equal-sized air guns with a total volume of $78.66 \mathrm{~L}\left(4800 \mathrm{in}^{3}\right)$, towed at $12 \mathrm{~m}$ depth and fired at $200 \mathrm{~m}$ intervals. Shooting was terminated near shore west of Lofoten and resumed again in Vestfjorden. The seismic data were recorded by ocean bottom seismometers (OBS) consisting of ISV three component analog or digital seismometers, or by GEOMAR digital three component seismometers combined with a hydrophone, or by hydrophone alone (OBH). Digital three-component land seismometers were deployed to extend the profile. Navigation was by the Differential Global Positioning System. The marine shot line is $281.4 \mathrm{~km}$ long, and extended by the land stations the seismic model is $342 \mathrm{~km}$ long. Of the 15 OBSs deployed, 11 recorded useful data. None of the 5 stations deployed in Lofoten gave data sets, and of the 6 land stations on the mainland 5 returned usable data, making a total of 16 data sets available for the modeling.

A $60 \mathrm{~s}$ record length was extracted after each shot, adjusted for instrumental clock drift, and tied to navigation. The OBS/H position was then corrected for physical instrument drift along profile estimated from the timing of the water arrival. Initial processing included de-biasing to ensure a symmetric pulse around $0 \mathrm{~V}$, bandpass filtering $(6-12 \mathrm{~Hz})$ to remove noise, and offset dependent scaling. This was then compared to a processing flow including spiking predictive deconvolution. The advantage of the first is that weak but coherent arrivals can be easier to recognize by the ringing nature of the signal, and the signal onset time is less affected by the processing. The advantage of the second is that later arrivals are less obscured by pulse-ringing from earlier arrivals, and appear cleaner. All seismic examples shown here are based on the latter sequence. The record 
sections are velocity reduced by $8 \mathrm{~km} \mathrm{~s}^{-1}$. All processing is done with Seismic Unix. Vertical reflections from the shots were also recorded by a single channel streamer, though the profile is of moderate quality and is not shown here. It was used to constrain seafloor depth and uppermost sedimentary layers for the start model.

The GeoMetrics G 801 proton precession magnetometer was only deployed during seismic shooting west of Lofoten, towed $180 \mathrm{~m}$ behind the ship. Readings were logged every $10 \mathrm{~s}$, and positioning was extrapolated from the GPS log using the average heading of the ship along profile. Base station noise measurements used to correct the data were from Sørøya, northern Norway. Positional and secular variations of the Earth's magnetic field were corrected by the International Geomagnetic Reference Field (IGRF, v.11). Final smoothing was performed with a $10 \mathrm{~km}$ wide Gaussian spatial filter from the GMT software (Wessel and Smith, 1991; Wessel et al., 2013). Gravity was recorded continuously at $10 \mathrm{~s}$ intervals by a LaCoste \& Romberg S-99 gravimeter mounted on a stabilized platform. Instrument drift was corrected by port measurements in Bergen, and absolute gravity established by a reference point at the University of Bergen. Smoothing was done with a $5 \mathrm{~km}$ wide Gaussian spatial filter.

\section{P-Wave Modeling}

Rayinvr is used for the modeling, which is a forward raytracing program with inversion functionality (Zelt and Smith, 1992). The inversion is node-specific and useful for finding solutions in complex settings, and to derive resolution statistics. The model is developed from top and downwards by fitting arrivals with increasing travel times.

By giving an uncertainty to the picked arrivals, the program will use $\chi^{2}$ statistical analysis to estimate the goodness of fit between model predictions and observations. A value of 1 or lower shows that the fit is within interpretation uncertainty. The uncertainty is set to approximately \pm the width of one cycle of the phase, since it is often difficult to pick the first onset of an arrival due to noise. Other sources for uncertainty are the shot timing, the instrument location (especially off-line), and the bathymetry (Hooft et al., 2000). Short offset arrivals from the sedimentary layers are estimated to $\pm 50 \mathrm{~ms}$, while Moho arrivals are assigned an uncertainty of $\pm 100 \mathrm{~ms}$ where clear. 
Greater uncertainty is assigned to indistinct arrivals. Most arrivals from the main layer boundaries have been modeled to a fit $\chi^{2} \leq 1$ (Tab. 1).

OBSs 59, 60, 62, and 64 did not record useful data. Most of the retrieved data sets are of high quality. All data sets, interpretations, and model reproductions can be found in the supplementary material. Data and models included here are shown in Figs. 3-9, and the resulting velocity model is shown in Fig. 10. The different parts of the model are described within a rough tectonic domain division below, referring to $\mathrm{km}$ position along the transect.

\subsection{Oceanic domain $(0-\sim 90 \mathrm{~km})$}

The oceanic basin has a $\sim 3 \mathrm{~km}$ thick sedimentary section derived mostly from glacial erosion of the Barents Sea (Hjelstuen et al., 2007). The velocities are constrained by long refracted arrivals $\left(\mathrm{P}_{x}\right)$ on OBSs 57 and 58, and range from $1.85 \mathrm{~km} \mathrm{~s}^{-1}$ at the top to $2.85 \mathrm{~km} \mathrm{~s}^{-1}$ at the bottom. The oceanic crust is constrained by OBSs 57, 58, and 61 (Fig. 3). Crustal arrivals show three distinct slopes, and three layers were therefore used to model the arrivals here. The northwestern $60 \mathrm{~km}$ of the profile has a crustal thickness of 5.5-6 km. Approaching the continent, oceanic crustal thickness increases up to $\sim 8 \mathrm{~km}$.

\subsection{Continent ocean transition $(\sim 90-105 \mathrm{~km})$}

The continent-ocean transition (COT) shows in the mid-crustal velocities, which falls from approx. 6.8 to $6.4 \mathrm{~km} \mathrm{~s}^{-1}$ over a distance of $10-15 \mathrm{~km}$. Magnetic seafloor spreading anomalies also start to appear at outer part of this zone (Fig. 10). Both OBS 61 and OBS 63 (Figs. 3 and 4) show seismic arrivals traveling through the uppermost mantle $\left(\mathrm{P}_{n}\right)$, constraining the oceanic crustal thickness next to the continent. Diving waves through the upper $\left(\mathrm{P}_{g 1}\right)$, middle $\left(\mathrm{P}_{g 2}\right)$, and lower crust $\left(\mathrm{P}_{g 3}\right)$ constrain the velocity there (Figs. 3-6). In particular OBS 67 and OBS 68 (Fig. 6) have long-offset diving waves through the lower continental crust.

\subsection{Lower crustal body $(\sim 75-150 \mathrm{~km})$}

Two reflections coming in after the crustal diving waves on OBS 61 and OBS 63 (Figs. 3 and 4) identify a distinct lower-crustal body (LCB) at the outer continental margin. The deepest has a high amplitude and fits with the $\mathrm{P}_{n}$ phase, and is therefore unambiguously identified as a 
Moho reflection $\left(\mathrm{P}_{M} \mathrm{P}\right)$. Above it is another strong reflection $\left(\mathrm{P}_{C} \mathrm{P}\right)$ originating at the top of the LCB. These OBSs illuminate partly overlapping areas in the lower crust from opposite directions. The high amplitude and good separation between the two reflectors show considerable seismic impedance contrasts both at the top and at the bottom. Farther landward, OBS 65 recorded a good reflection from the top of this layer, but also a diving wave traveling through major parts of the layer $\left(\mathrm{P}_{g 4}\right)$. This constrains the velocity of the upper parts of this body to be about $6.9-7.1 \mathrm{~km} \mathrm{~s}^{-1}$. Similar arrivals are seen on OBS 66, albeit a noisier and poorer data set which proved harder to fit. Further constraints on Moho depth at this layer are given by $\mathrm{P}_{n}$ phases traveling through it at increasing offsets from OBS/Hs 67 to 71, and from land station 7 (Figs. 6-8). In order to trace rays to all observed arrivals, the layer was allowed to continue past the COT, where it essentially forms part of the lowermost oceanic crust.

\subsection{Outer continental margin $(\sim 105-170 \mathrm{~km})$}

This part of the model is densely sampled by diving waves on OBSs 61 to 69 (Figs. 3-6). The top of the crystalline continental crust here is at approx. $7 \mathrm{~km}$ depth, and the crust overlays the LCB. It has a fairly low P-wave velocity of $6.0-6.4 \mathrm{~km} \mathrm{~s}^{-1}$, and has a minimum thickness of about $4.5 \mathrm{~km}$ around $125-130 \mathrm{~km}$ in the model. It thickens by $\sim 1 \mathrm{~km}$ towards the COT, leading into an even thicker oceanic crust at $90 \mathrm{~km}$ in the model, similar to what was observed farther south on the Lofoten Margin (Mjelde et al., 1992). Resting on top of the crystalline crust, there is a layer of $5.0-5.5 \mathrm{~km} \mathrm{~s}^{-1}$ velocities, with thickness varying from $2 \mathrm{~km}$ to almost $5 \mathrm{~km}$ due to the high relief on top. Above this layer, the sedimentary velocities of the continental slope are high, $2.9 \mathrm{~km} \mathrm{~s}^{-1}$ to $4.3 \mathrm{~km} \mathrm{~s}^{-1}$ from top to bottom. Distal parts of the margin have significantly lower sedimentary velocities (1.85 $\mathrm{km} \mathrm{s}^{-1}$ to $2.85 \mathrm{~km} \mathrm{~s}^{-1}$ from top to bottom).

\subsection{The continental shelf and land areas $(\sim 170-342 \mathrm{~km})$}

Just east of the shelf edge the profile crosses the northern part of the Utrøst Ridge (Jennegga High) (Fig. 10). The top basement is only covered by a thin layer of sedimentary rocks, and it stands out in the travel times of waves traveling both deep and shallow. OBS/Hs 61 to 71 give good velocity control down to mid-crustal levels at 150-200 model km (Figs. 3-6). Most land 
stations record deep reflections that travel through the high (Fig. 8). The velocity is significantly higher throughout the crust here compared to that of the outer margin. It increases from 6.3 $\mathrm{km} \mathrm{s}^{-1}$ at the top to about $6.7 \mathrm{~km} \mathrm{~s}^{-1}$ at $16-18 \mathrm{~km}$ depth. There is strong intra-crustal reflectivity $\left(\mathrm{P}_{G} \mathrm{P}\right)$ originating from mid-lower crustal levels here, seen on $\mathrm{OBH} 70$ and $\mathrm{OBS} 71$, and on land stations 7 and 9 (Figs. 7-8). An extra layer was introduced to model these arrivals. In order to best fit the strong reflection on station 7 seen between 160 and 240 model $\mathrm{km}$, it was made deeper eastwards, but the termination at the Moho is not constrained. There is some lower-crustal reflectivity observed also farther to the east, but it is not consistent between instruments, and was modeled by floating reflectors. There are no velocity constraints of this lower-crustal region on Profile 6-03, but the crossing Profile 8-03 (Breivik et al., in prep.) shows a Moho depth of $30 \mathrm{~km}$ consistent with Profile 6-03, and a lower crustal velocity of $6.8-6.9 \mathrm{~km} \mathrm{~s}^{-1}$ at the tie.

The crustal thickness increases rapidly underneath the Jennegga High, but does not reach the maximum of $36 \mathrm{~km}$ thickness before close to Lofoten. This increase is mainly constrained by $\mathrm{P}_{n}$ phases from OBS/Hs 68 to 71 and from land station 7 (Figs. 6-8). The Moho is significantly deeper than the updoming $20 \mathrm{~km}$ depth reported underneath southwestern parts of Lofoten (Mjelde et al., 1996), and the $26 \mathrm{~km}$ depth reported offshore Lofoten/Vesterålen (Sellevoll, 1983). The upper-crustal velocities under Lofoten are between $5.8 \mathrm{~km} \mathrm{~s}^{-1}$ and $6.1 \mathrm{~km} \mathrm{~s}^{-1}$, which are low for crystalline rocks. This is well constrained by shallow refracted waves from OBS/Hs 66 to 71 (Figs. 6-7), 6 stations in all.

Sedimentary rock layers in the northern Ribban Basin (Fig. 10, 180-230 model km) are best constrained by OBS 67 and OBS 68 (Fig. 6), showing a maximum thickness of about $3 \mathrm{~km}$. Two layers with a marked velocity contrast were modeled. The lower appears well consolidated with velocities of 4.5-5.0 $\mathrm{km} \mathrm{s}^{-1}$, actually highest in the shallowest part next to Lofoten. The velocity of the upper layer is about $3.5 \mathrm{~km} \mathrm{~s}^{-1}$, similar to that of the upper layer of the outer margin. The profile crosses the inner part of the Vestfjorden basin (250-290 model km), which is a half-graben here, downfaulted to the east to a depth of $2 \mathrm{~km}$. Constraints are given by OBS 69 west of Lofoten, by OBH 70 (Fig. 7) and OBS 71 within Vestfjorden, and by land stations 6 to 9 (Fig. 8) to the east. The velocities of the upper sedimentary layer here are similar to that of the Ribban Basin, but slightly lower (4.2-4.3 $\left.\mathrm{km} \mathrm{s}^{-1}\right)$ in the deepest layer. Top basement velocities are at $6.0-6.2 \mathrm{~km} \mathrm{~s}^{-1}$ 
slightly higher here than under Lofoten. Both land stations 6 and 7 (Fig. 8) require increased (6.2 $\mathrm{km} \mathrm{s}^{-1}$ ) uppermost basement velocities for the first $10 \mathrm{~km}$ on the eastern side of Vestfjorden, while the stations farther from the coast indicate slightly lower velocities around $6.0 \mathrm{~km} \mathrm{~s}^{-1}$.

Upper and middle crust underneath Lofoten $(\sim 200-260 \mathrm{~km})$ easily transmit diving waves, but for land stations farther eastwards only the top of the lower crust at $15 \mathrm{~km}$ depth underneath Lofoten would support diving waves (Fig. 9). This interface is also a strong reflector. For land station 11, all arrivals east of $210 \mathrm{~km}$ in the model had to be reflected at this level or deeper. The only way to explain this, would be that there is little (or negative) velocity gradient throughout the upper part of the crust here, extending from the mainland to under the Vestfjorden Basin. For the part west of $210 \mathrm{~km}$, reflected and refracted waves can both reproduce the observed arrival times.

\subsection{Model coverage and resolution}

The fit statistics for the most important phases are shown in Table 1. The fit is poorer where arrivals could only be traced to observed locations as head waves due to model complexity. The average $\chi^{2}$ value for all phases is just below 1 . The ray coverage density is highest in the upper middle crust, and the continental margin down to the uppermost mantle (Fig. 11A). Lower crust is thinly covered underneath the continental shelf. The quality of constraints for individual velocity nodes can be estimated by gridding the diagonal values of the resolution matrix for boundary nodes obtained from the inversion tool in Rayinvr (Fig. 11B). Only velocity was inverted while the geometry was held fixed. Values range from 1 (best) to 0 , and values above 0.5 indicate a reasonably well resolved parameter (Zelt and Smith, 1992). The analysis is based only on refracted phases, since reflections do not put strong constraints on velocity in the model. Also $\mathrm{P}_{M} \mathrm{P}$ phases were excluded, since these lacked sufficient moveout to be useful. Including short-offset reflections in the velocity inversion within a fixed geometry model gives an unrealistically high parameter resolution estimate.

Sedimentary velocities are well constrained in the oceanic basin, as well as at the outer margin down to basement. Basement velocities are well resolved under the Vestfjorden Basin, and at upper-mid-crustal levels underneath Lofoten. Also mantle velocities at the outer margin are well controlled at $8.0 \mathrm{~km} \mathrm{~s}^{-1}$, and somewhat less under the oceanic crust, where the modeling indicates 
$8.1 \mathrm{~km} \mathrm{~s}^{-1}$. Also velocities of the oceanic crust and the lower crustal body at the margin are less well constrained, in part due to the loss of data from four OBSs deployed here. Lower crustal velocities are poorly resolved in general.

The depth node resolution can be estimated in a similar fashion. The velocity was held fixed, while depth nodes were inverted with both refractions and reflections. Four levels were tested; the boundary between upper and middle crust, middle and lower crust, the top of lower crustal layers, and the Moho. Depth node resolution is shown by the size of the circles enclosing them, where larger is better (Fig. 11B). The depth to the boundary between the crystalline crust and the sedimentary rocks at the outer margin is well resolved. While mid-crustal velocities are well constrained under Lofoten, the depth between upper and middle crust is not precisely located. The top of the lower crust is not well resolved in general, though it is better in areas giving many reflections. The depth to the top of the lower crustal body at the outer margin is well constrained, and so is the Moho depth underneath it, as well as the oceanic Moho to the west. The $36 \mathrm{~km}$ continental Moho depth is reasonably constrained at the outermost part underneath Vestfjorden and Lofoten.

Resolution tests show how independent adjacent nodes are from each other, where a low resolution indicate a spatial smearing of node values. However, the resolution plot does not quantify parameter error bounds, and low values does not mean that the data cannot constrain a solution. A direct approach was therefore used in order to estimate model sensitivity to changes (e.g., Zelt, 1999). Due to the large number of models that needs to be generated, only outer margin features important for the discussion were investigated. This includes the lower-crustal body, and the continental crust directly above it.

Using $\mathrm{P}_{g 4}, \mathrm{P}_{M} \mathrm{P}$, and $\mathrm{P}_{n}$ phases for Moho depth and LCB velocity nodes located between 80 and $140 \mathrm{~km}$ in the model, a total of 1701 models were run using an automated procedure. Depth nodes are adjusted the same direction incrementally by $0.1 \mathrm{~km}$ steps, while velocity nodes (top and bottom layer) are similarly adjusted incrementally by $0.01 \mathrm{~km} \mathrm{~s}^{-1}$ steps through a range of values for each depth increment. Fit statistics for these models were extracted and presented in Fig. 12A and B, while the phases used are shown in Fig. 12C. As can be seen from the $\chi^{2}$ values, the preferred velocities $\left(6.9-7.1 \mathrm{~km} \mathrm{~s}^{-1}\right)$ were chosen at the higher range of possible solutions 
within a $\chi^{2} \leq 1$. This was justified by emphasizing the slope of the observed $\mathrm{P}_{g 4}$ phases more than minimizing $\chi^{2}$. The model will not support much higher velocities within the interpretation uncertainty for the LCB, but velocities reduced by up to $-0.25 \mathrm{~km} \mathrm{~s}^{-1}$ can be accommodated by making the Moho $0.6 \mathrm{~km}$ shallower. Within the possible higher velocities, the Moho could be up to $0.3 \mathrm{~km}$ deeper.

This procedure was also applied to the crustal layer above it, where continental crustal velocities are significantly lower $\left(6.3-6.45 \mathrm{~km} \mathrm{~s}^{-1}\right)$. Velocities were allowed to vary together with the depth to the top of the LCB. A total of 1275 different models were run, giving the fit statistics shown in Fig. 12D and E. The phases used are shown in Fig. $12 \mathrm{~F}$, and include $\mathrm{P}_{g 3}, \mathrm{P}_{C} \mathrm{P}$, and $\mathrm{P}_{g 4}$. Acceptable velocity variations lie between $+0.12 \mathrm{~km} \mathrm{~s}^{-1}$ to $-0.15 \mathrm{~km} \mathrm{~s}^{-1}$. The model search stopped at $1.2 \mathrm{~km}$ deeper top-LCB, as it was limited by the Moho depth below within the range. Top-LCB shallower than $0.5 \mathrm{~km}$ resulted in increasing difficulties tracing rays through the model.

\section{Magnetic modeling}

The continental breakup is constrained by using ship track magnetic data from the survey, which are compared to previous studies of the early plate spreading rates in the NE Atlantic (Breivik et al., 2006, 2009, 2012). Old magnetic data did not have the necessary navigation accuracy for high-precision work, so new GPS-navigated ship track data were used exclusively. Magnetic anomalies at the most magma-productive parts, created by subaerial eruptions and long lava flows, do not record reliable time lines, therefore only margin segments with lesser magmatism were targeted. One of the best margin segments to study early seafloor spreading rates is the northern Møre Margin where breakup magmatism was moderate. It shows a high half-spreading rate of $29-32 \mathrm{~mm} \mathrm{y}^{-1}$ for the first $\sim 2 \mathrm{~m}$.y. (Breivik et al., 2006). This result was later largely reproduced at the conjugate volcanic margin off the Jan Mayen micro-continent (Breivik et al., 2012). Similar rates were also found at the northern edge of the Vøring Plateau, $250 \mathrm{~km}$ southwest of our study area (Breivik et al., 2009). These results show both higher early spreading rates and more consistency than the study of Mosar et al. (2002), based on vintage data.

The half-spreading rates of Breivik et al. (2006) were used to make a start model of the seafloor spreading with blocks of normal and reversely magnetized sections (Fig. 13). Older studies were 
based on the Cande and Kent (1995) geomagnetic polarity time scale, which we also use here in order to ensure that rates are comparable. The magnetic response of synthetic models was calculated by an FFT routine, using a depth of $5.5 \mathrm{~km}$ to the top of a $2 \mathrm{~km}$ thick magnetized layer, and a magnetization of $4.2 \mathrm{~A} \mathrm{~m}^{-1}$ (Rabinowitz and LaBreque, 1979). Amplitudes are reproduced reasonably well, and spreading rates were adjusted for the best visual fit to the ship track. The rates are projected by $20^{\circ}$ onto the estimated spreading direction. These are comparable to that of the Møre Margin within an uncertainty of $\pm 2 \mathrm{~mm} \mathrm{y}^{-1}$, except for the earliest stage, between anomalies 24a (C24n.1n) and 24b (C24n.3n). A fit could only be obtained by using a low rate of 20 $\mathrm{mm} \mathrm{y}^{-1}$, which is not reasonable from a plate tectonic perspective. However, by assuming a crustal breakup time during the normal $24 \mathrm{~b}$ anomaly at $53.1 \mathrm{Ma}$, a reasonable fit could be obtained using a rate of $29 \mathrm{~mm} \mathrm{y}^{-1}$ compatible with the older studies (Fig. 13). The fit became much poorer with 0.1 m.y. younger or older breakup times. Also, the spreading rate could not be increased above 29 $\mathrm{mm} \mathrm{y}^{-1}$, since anomaly $24 \mathrm{a}$ then became too dominant.

\section{Discussion}

\subsection{Continental crustal structure}

The lack of turning rays prevented direct velocity measurements in the deeper crust east of Vestfjorden, but that also constrains the velocity increase with depth to be low. The modeled depth to the middle-crustal reflective level is $15-15.5 \mathrm{~km}$. Upper-crustal velocity is $\sim 6.0 \mathrm{~km} \mathrm{~s}^{-1}$, which was increased to $6.3 \mathrm{~km} \mathrm{~s}^{-1}$ at $15 \mathrm{~km}$ depth. With uniform composition, the pressure increase will give a velocity increase, but this is dampened by the rising temperature (Christensen and Mooney, 1995). Tests show that by using a zero velocity gradient the depth to this reflector is decreased by $\sim 1 \mathrm{~km}$, giving a minimum depth estimate of $14 \mathrm{~km}$. The area has a prominent Bouguer gravity low (Fig. 14A), related to a huge granitoid body within the Trans-Scandinavian Igneous Belt (TIB), which dates back to the Proterozoic (1.86-1.65 Ga) (Olesen et al., 2002; Gradmann and Ebbing, 2015). This is the largest gravity anomaly within the TIB, extending $\sim 50 \mathrm{~km}$ into Sweden. Gravity models indicate a bottom depth of this body of up to $20 \mathrm{~km}$ in central parts (Olesen et al., 2002; Gradmann and Ebbing, 2015). However, with the heat production expected for granitic rocks, 
more than $12 \mathrm{~km}$ thickness would produce a higher heat flow than observed (Pascal et al., 2007). The strong reflector at $14-15 \mathrm{~km}$ depth most likely comes from the bottom of this body under Vestfjorden and the coastal mainland, and is the first seismic candidate for the bottom of a TIB intrusion. However, this is at the outer edge of the batholith (Fig. 14A), and central parts may be significantly thicker. That would require the radioactive heat production to be lower than expected.

Direct velocity measurements could be obtained in the uppermost crust adjacent to Vestfjorden. Land stations 6 and 7 (Fig. 8) required a local increase from $6.0 \mathrm{~km} \mathrm{~s}^{-1}$ to at least $6.2 \mathrm{~km} \mathrm{~s}^{-1}$. Station 6 still has a poor fit, and would require higher velocities than could be handled within the model geometry. It seems to be related to a local outcrop of intermediate mangerite syenite on the adjacent land, bordered by more granitic retrograded rocks to the east (e.g., Schlinger, 1985), [geo.ngu.no/kart/berggrunn]. The area has a corresponding positive magnetic anomaly, surrounded by low positive or negative amplitudes (Fig. 14B).

Precambrian rocks are exposed in Lofoten, consisting mainly of high grade charnokites, mangerites, and supra-crustals (Griffin et al., 1978). The upper-crustal velocities of 5.8-5.9 $\mathrm{km} \mathrm{s}^{-1}$ found under inner Lofoten are similar to velocities measured (pressure corrected) on granitic and monzodioritic gneiss outcrops on Austvågøya (Chroston and Brooks, 1989). Rocks outcropping on the southern end of Austvågøya are quite acidic (Ormaasen, 1977), and the more granitic rocks probably form the bulk crustal composition for the upper $\sim 5 \mathrm{~km}$ underneath larger parts of the island. Velocities are somewhat higher at mid-crustal levels, but at $6.1-6.2 \mathrm{~km} \mathrm{~s}^{-1}$ they are still quite low.

Upper-crustal velocity increases to $6.3 \mathrm{~km} \mathrm{~s}^{-1}$ in the northern Utrøst Ridge (Jennegga High), where the strongest positive gravity anomaly is observed along profile (Fig. 10). The velocity increases to about $6.7 \mathrm{~km} \mathrm{~s}^{-1}$ down to mid-crustal levels, so this appears to be a deeply rooted crustal terrain. It is uncertain if it is continuous with the lowermost continental crustal layer underneath the outer part of the shelf, where the crossing Profile 8-03 shows a 6.8-6.9 $\mathrm{km} \mathrm{s}^{-1}$ velocity. The top/inner side of this zone is highly reflective underneath the inner Utrøst Ridge and the Ribban Basin. This is also an area with rapid crustal thinning towards the outer margin.

The regional magnetic signatures of the Lofoten islands and the Utrøst Ridge are very similar. The strong, positive anomalies follow the NE-SW orientation of the basement highs (Fig. 14B). 
The gravity map shows the same pattern, but there is a relative gravity low in the inner part of Lofoten where Profile 6-03 crosses (Fig. 14A), associated with upper-crustal felsic rocks. High gravity anomalies are found farther to the southwest in Lofoten, and in Vesterålen. The positive magnetic anomalies merge in Vesterålen, while the positive gravity anomalies are narrower, and the northern part is not continuous with, and located between the ridges farther south. Thus, the magnetic signature seems to follow the basement structure of the ridges more than the density distribution. Metamorphic facies apparently determines this, since granulite facies rocks exposed throughout Lofoten have stronger magnetization than amphibolite and eclogite facies rocks (Schlinger, 1985).

The Lofoten/Vesterålen area was not much affected by the Caledonian orogeny, despite being located in the middle of the collision zone. Griffin et al. (1978) proposed that the area remained a high-level crustal block during the orogeny due to its massive dry granulite-facies rocks, resisting deformation. Similarity of the gravity field (Fig. 14) combined with our velocity data, suggest that the crust underneath both the Utrøst Ridge and Vesterålen-SW Lofoten ridge may be relatively mafic in composition. That will give a strong crust for the entire shelf area (e.g., Kusznir and Park, 1987), in agreement with this.

The sedimentary basins on the shelf comprise the Vestfjorden and Ribban basins, which are only 2 and $3 \mathrm{~km}$ deep at the profile, respectively. The small peak within the Ribban Basin corresponds to a rotated fault block with east-dipping faults seen in reflection seismic data (Tsikalas et al., 2001). Top sedimentary layer velocities are quite high (3-3.6 $\left.\mathrm{km} \mathrm{s}^{-1}\right)$, suggesting deeper burial earlier, and truncation of reflectors shows substantial erosion of the area (Løseth and Tveten, 1996). Our results are consistent with the proposal that mid-Jurassic-Cretaceous strata often rest directly on crystalline bedrock (Løseth and Tveten, 1996; Færseth, 2012), though a thin sequence of older sedimentary strata cannot be ruled out. Pre-Cretaceous sediments are thicker farther southwest on the Lofoten shelf and in the Vestfjorden Basin (Mjelde et al., 1996; Bergh et al., 2007; Hansen et al., 2012). 


\subsection{Continental breakup}

The Lofoten/Vesterålen Margin has been described as an atypical volcanic margin (e.g., Talwani et al., 1983; Mjelde et al., 1993; Kodaira et al., 1995; Berndt et al., 2001; Tsikalas et al., 2001), first of all having large quantities of extrusive magmatism on the continental side, but also seaward dipping reflector sequences, and an oceanic crust somewhat thicker than normal produced immediately after breakup. Older OBS profiles north of the Vøring Plateau are located midway between the Plateau and this profile (Mjelde et al., 1992; Kodaira et al., 1995). The profiles of Mjelde et al. (1992) both resemble and differ from our profile. A common feature is the thin continental crust of the outer $50-60 \mathrm{~km}$ of the margin. At our profile, the crystalline crust is $\sim 4.5 \mathrm{~km}$ thick at minimum (Fig. 10), comparable to the 5-7 km observed on the older profiles. Mjelde et al. (1992) reported massive lava flows farther south, but that was not observed here. Note that none of these older profiles show any high-velocity lower crustal bodies usually interpreted as igneous intrusive complexes in the lower continental crust, as seen at the Vøring Plateau (Mjelde et al., $2005 \mathrm{~b}$ ) to the southwest and at other volcanic margins. Our profile is therefore the first to identify such a layer at the Lofoten/Vesterålen margin.

\subsubsection{Extrusive magmatism}

Extrusive volcanic layers at the Lofoten/Vesterålen Margin have previously been interpreted from a number of features, including strong reflectors, chaotic sequences, and mounds (Talwani et al., 1983; Mjelde et al., 1992, 1993; Mokhtari and Pegrum, 1992; Berndt et al., 2001; Tsikalas et al., 2001; Tasrianto and Escalona, 2015). On some seismic profiles, a strong reflector can be followed from oceanic crust in the west and up to the shelf edge (Fig. 2). Figure 9 of Tasrianto and Escalona (2015) shows a seismic line just to the north of our profile showing this. They interpret the reflection as top basalt only for the lower part, merging with a base Cenozoic unconformity in the higher part. The interpretation of the base Cenozoic unconformity seems reasonable, but most likely it should be extended to the foot of the slope without basalts on top.

Farther to the south, the OBS models of Mjelde et al. (1992) indicate that a basaltic layer could be $2-3 \mathrm{~km}$ thick, with a velocity inversion underneath. However, basaltic lava is rich in magnetite and layers this massive are expected to have a strong magnetic signature as seen for the landward 
flows on the Vøring Plateau (Ebbing et al., 2009). The Lofoten/Vesterålen Margin has a remarkably subdued magnetic anomaly field (Fig. 14B), showing no indications of the proposed extent, nor of the $\sim 4 \mathrm{~km}$ variation in depth to the top of the layer. Some basaltic flows are expected, but they are most probably of a much lesser volume. On the other hand, there is a good correlation between the outer margin seaward dipping reflectors from Berndt et al. (2001) and the seafloor spreading magnetic anomalies in the south (Fig. 14B). However, there is an increasing discrepancy between proposed seaward dipping reflector sequences and the magnetic field towards the north, where also the mounds previously interpreted as volcanic outer highs (Berndt et al., 2001; Tsikalas et al., 2001) lack a magnetic signature. Data coverage has increased greatly since then, and newer sidescan bathymetry shows that mass wasting from the shelf created the mounds and chaotic deposits (Thorsnes et al., 2009; Rise et al., 2013) (Fig. 2).

Older OBS surveys (Mjelde et al., 1992; Kodaira et al., 1995) as well as Profile 6-03 agree that the early post-breakup magmatism is moderately elevated, but of lesser magnitude than at the Vøring Plateau (Breivik et al., 2009). Both the continental crust and the adjacent oceanic crust at the Lofoten/Vesterålen Margin are much thinner and lie 3-4 km deeper than at the Vøring Plateau, and sub-aerial eruptions at breakup are not expected here. It therefore seems unlikely that lava flows could reach areas near the shelf edge as proposed (Fig. 2). On the Vøring Plateau there are also a number of sill complexes within the sedimentary strata, extending far landward of the Vøring Escarpment (Planke et al., 2005). This is not observed at the Lofoten/Vesterålen Margin. Some of the sills have high velocities $\left(7.0-7.4 \mathrm{~km} \mathrm{~s}^{-1}\right)$ similar to that observed for the lower-crustal bodies of the outer margin (Berndt et al., 2000).

Observations that led to the interpretation of extensive lava flows at the margin may have several origins in addition to mass wasting, and can differ from area to area. Higher up on the continental slope, the most likely explanation for a strong reflection is a base- or early-Cenozoic unconformity, exposing well-consolidated Cretaceous sedimentary rocks. On the outer margin the distal turbidites from the Barents Sea (Hjelstuen et al., 2007) are poorly consolidated and overlap slope sediments and deeper sedimentary rock layers. At Profile 6-03, these deposits reach a bottom velocity of $2.25 \mathrm{~km} \mathrm{~s}^{-1}$, where they onlap a layer most likely consisting of sedimentary rocks with a velocity of $4.3 \mathrm{~km} \mathrm{~s}^{-1}$. There is also a velocity contrast between the distal turbidites and the 
margin-derived sediments in the fan deposits, the latter having velocities of $2.9-3.2 \mathrm{~km} \mathrm{~s}^{-1}$ at Profile 6-03. Both interfaces could create strong reflections.

\subsubsection{Intrusive magmatism}

High-velocity lower-crustal bodies (LCB) are ubiquitous at volcanic passive margins around the world (e.g., Eldholm and Coffin, 2000; White et al., 2008). The velocity of the LCB observed at the outer margin on our profile is consistent with intruded magmatic material at the bottom of or within the lower continental crust, although alternative interpretations of the lower crustal bodies observed at volcanic margins have been proposed (e.g., Gernigon et al., 2004). Since the crystalline crust is severely stretched, serpentinization of the uppermost mantle could lower the velocity to observed values if seawater percolated to these depths (e.g., Whitmarsh et al., 2001). However, this mechanism will result in a gradual decrease of serpentinization with depth, resulting in a strong velocity gradient and a weak or non-existent seismic Moho (Chian et al., 1999). There is apparently little velocity gradient within the body on Profile 6-03, and Moho reflections have high amplitudes, thus the observations are clearly inconsistent with serpentinization.

Another possible explanation for the high lower crustal velocities could be the presence of mafic granulites dating back to the formation of the continental crust. This is unlikely since both the Moho depth and the velocity are continuous with the lower oceanic crust to the west, indicating that these were created together through the same process. The velocity within the LCB is lower (6.9-7.1 $\mathrm{km} \mathrm{s}^{-1}$ ) than seen in similar bodies at the Vøring Plateau or at the East Greenland Margin conjugate to the Plateau (Mjelde et al., 2005a; Voss and Jokat, 2007), where it is 7.2-7.4 $\mathrm{km} \mathrm{s}^{-1}$. On the other hand, farther north on the East Greenland Margin and conjugate to our study, both lesser magmatism and lower LCB velocities $\left(7.1 \mathrm{~km} \mathrm{~s}^{-1}\right)$ are observed (Voss et al., 2009).

White et al. (2008) reported the results of combined OBS and deep penetration multi-channel seismic reflection data at the outer Faeroes Margin, and concluded that the lower-crustal body there consists of layered intrusions into the lower crust. According to this, they raised the question of to what degree the observed velocities will be representative of the intruded rocks. If the velocity results from a mix of original continental and intruded rocks, the measured velocity could differ significantly from that of the intruded rocks themselves, and could therefore bias the interpreta- 
tion of the processes forming them (White and Smith, 2009). Our preferred model shows LCB velocities only slightly lower than the adjacent lower oceanic crust, and significantly lower than that of the Vøring Plateau to the south. That would indicate a lower mantle melting degree, resulting in increased $\mathrm{FeO}$ over $\mathrm{MgO}$ content giving lower velocities (White and McKenzie, 1989). Even if intruded rock velocities could be higher than that observed for the LCB as a whole, the moderate melt volume observed is consistent with this; the size of the LCB is lesser than that observed at e.g., the Vøring Plateau, and the excess post-breakup magmatism is short-lived and only moderately elevated.

There is a $0.2 \mathrm{~km} \mathrm{~s}^{-1}$ fall of the LCB velocity from the oceanic to the continental side, which may suggest a decrease of igneous rocks within the LCB away from the COT, similar to what is observed at the Faeroes Margin (White et al., 2008). In order to estimate how large a fraction of the LCB could consist of intrusions, we apply a linear mixing model between two components as used by White and Smith (2009). If we assume an igneous rock velocity of $7.1 \mathrm{~km} \mathrm{~s}^{-1}$ and a crustal velocity of $6.4 \mathrm{~km} \mathrm{~s}^{-1}$, and an average LCB velocity of $7.0 \mathrm{~km} \mathrm{~s}^{-1}$, the LCB would consist of about $85 \%$ intrusive rocks. These values are derived from the lower-continental/oceanic rock velocities here, and the LCB velocities of the preferred model. However, as shown in Fig. 12 the data will support lower velocities in the LCB, and using a lower average LCB velocity of $6.8 \mathrm{~km} \mathrm{~s}^{-1}$ will bring the intruded fraction down to below $60 \%$. Thus it seems reasonable to conclude that the LCB is an intrusive complex in the lowermost continental crust with a reduction of intrusions landward, and that the intruded volume could be significantly less than the observed LCB thickness would suggest.

\subsubsection{Tectonic development}

The Early Cretaceous rift phase at the Møre and Vøring basins created crust-penetrating detachment faults and deep sedimentary basins (Brekke, 2000; Osmundsen and Ebbing, 2008). Early Eocene crustal breakup occurred marginal to these basins, with less extension of the crust (Mutter and Zehnder, 1988; Mjelde et al., 2005a; Breivik et al., 2006), similar to that of the Hatton Bank and Faeroes margins (White et al., 2008). The crustal extension at the outer Lofoten/Vesterålen Margin was clearly strong around breakup, and produced a thinner crust than at the outer Møre 
and Vøring margins. Below the thin post-breakup sediments, the upper sedimentary rock layer has velocities comparable to the Cretaceous rocks on the shelf. Below this, the sedimentary rock layer has velocities of 5.0-5.5 $\mathrm{km} \mathrm{s}^{-1}$, and rests on basement. These velocities are only slightly higher than the deeper Cretaceous layer in the Ribban and Vestfjorden basins, and may correspond to this. The deposits could be primarily of Early Cretaceous age since this extension phase is important in the area (Løseth and Tveten, 1996), though it could also encompass older deposits.

The high relief of the top of the lower sedimentary rock layer is consistent with rotated fault blocks expected to develop in upper crustal rocks under extension. Figure 15 shows a tectonic model which can explain this geometry by low-angle detachment faults leading up to continental breakup. One of the faults then exposes Cretaceous rocks at the upper continental slope. The sedimentary rocks at the outer margin were presumably denuded by another detachment fault exposing deeper levels, though the hanging wall block must then be at the conjugate Northeast Greenland margin. Whether this connected with the adjacent landward detachment fault is uncertain, but it can explain the well-consolidated sedimentary rocks exposed underneath the margin-derived sediments.

Most publications agree that continental breakup in the NE Atlantic took place during the magnetic polarity Chron C24r (e.g., Eldholm et al., 1995; Mosar et al., 2002; Mutter and Zehnder, 1988; Skogseid et al., 2000; Torsvik et al., 2001). Voss et al. (2009) proposed a later breakup at the East Greenland Margin, progressing southwards conjugate to the Vøring Plateau. However, their COT is inconsistent with results on the Norwegian side (Mjelde et al., 2002, 2005a; Breivik et al., 2009, 2014), which indicate a C24r breakup. According to the widely used geomagnetic polarity time scale of Cande and Kent (1995), this extends from 53.35 Ma to 55.9 Ma, and most authors use $55 \mathrm{Ma}$ or $54 \mathrm{Ma}$ for breakup. The younger age is preferred on the Møre and Vøring margins due to the high early seafloor spreading rates. The newer Ogg (2012) polarity time scale could place these estimates more than 1 m.y. further back in time. However, the relative differences between margin segments are important here, and the data show that breakup on the Lofoten/Vesterålen Margin occurred $\sim 1$ m.y. later than farther south. With the established spreading rates, this delay would give $\sim 30 \mathrm{~km}$ of additional extension of the outer margin, which is not much more than 60 $\mathrm{km}$ wide, consistent with the thin crust observed. 
While brittle faulting is consistent with the blocky upper-crustal sedimentary rock configuration, the crystalline lower crust is smooth and appears to have undergone ductile deformation (Fig. 15). Between 100 and $160 \mathrm{~km}$ in the model, the upper-crustal sedimentary rock layers have an average thickness of $\sim 4.5 \mathrm{~km}$, and the crystalline lower crust a thickness of $\sim 6.5 \mathrm{~km}$. A $\beta$ factor of 3 would give a $33 \mathrm{~km}$ thick pre-breakup crust, including a sedimentary basin $13-14 \mathrm{~km}$ deep. This is a reasonable upper estimate, since comparable parts of the Late Jurassic-Cretaceous basins in the Barents Sea have a crustal thickness of 25-29 km (Breivik et al., 1998). The thin crust is therefore the result of several extensional phases, where the Mesozoic and Early Cenozoic phases most likely are the largest. From a crystalline crustal thickness of $36 \mathrm{~km}$ as seen in inner part of Lofoten, this gives a cumulative $\beta$-factor of $\sim 5.5$.

With a current margin $\sim 60 \mathrm{~km}$ wide and using a $\beta$-factor of 3 , the area would have been $\sim 20$ $\mathrm{km}$ wide at the onset of breakup. Over the last $1 \mathrm{~m} . \mathrm{y}$. before breakup, an extension rate of 30 $\mathrm{mm} \mathrm{y}^{-1}$ would produce $30 \mathrm{~km}$ of extension. In order to calculate the strain rate for this phase, we use a $30 \mathrm{~km}$ wide block, assuming some extension before the last phase. This gives a strain rate of $3.2 \cdot 10^{-14} \mathrm{~s}^{-1}$ leading up to breakup. The crystalline crustal velocity is consistent with a felsic composition, and combined with the high estimated strain rate, the models of Pérez-Gussinyé and Reston (2001) indicate that the lower crust should not become brittle, since it had little time to cool. Also, seawater will not effectively reach the mantle before the entire crust becomes brittle, consistent with the observed absence of upper mantle serpentinization. The fault heaves of the proposed two inner detachment faults are estimated to be $\sim 13-15 \mathrm{~km}$ each (Fig. 15), suggesting 26-30 km of extension, in good agreement with the plate-spreading based calculations.

Magma-poor rifted margins see strong crustal extension and upper mantle serpentinization leading up to continental breakup (e.g., Whitmarsh et al., 2001; Unternehr et al., 2010). The palinspastic reconstruction of the last extensional phase of an Iberian abyssal plain profile by Whitmarsh et al. (2001) can be used to estimate strain rate. Early extension is assumed to have occurred on crustal detachments soling out at mid-crustal level, eventually reducing crustal thickness down to $\sim 7 \mathrm{~km}$. At this stage, the width of the crustal block was approximately $25 \mathrm{~km}$, and the extension rate was $3.5 \mathrm{~mm} \mathrm{y}^{-1}$ over the last $\sim 9 \mathrm{~m}$.y. leading up to breakup. That gives a strain rate of $4.4 \cdot 10^{-15} \mathrm{~s}^{-1}$, which is close to one order of magnitude lower than at the Lofoten/Vesterålen 
Margin. The mantle would cool more since it rose slower, and thus produced little magmatism as observed. According to the model, detachments at this stage soled out in the upper mantle causing serpentinization, and one detachment unroofed partly serpentinized sub-continental mantle to the seafloor. Once continental separation was complete, seafloor spreading occurred at a higher half-rate of $10 \mathrm{~mm} \mathrm{y}^{-1}$, eventually producing igneous oceanic crust.

Volcanic passive margins evolve very differently with a low degree of crustal stretching during the breakup phase, and are characterized by extensive intrusive and extrusive magmatism (e.g., Mutter and Zehnder, 1988; White et al., 2008). The East African Rift System represent a volcanic margin under formation, in some places past crustal breakup (Bastow et al., 2011). Extension is accommodated by lower-crustal gabbroic intrusions, compensating for the crustal thinning (Bastow et al., 2011; Stab et al., 2016). This process is also observed under the Baikal rift zone (Thybo and Nielsen, 2009), and shows how the magmatic lower-crustal intrusions commonly observed on volcanic margins can be emplaced before final crustal breakup. Extension appears to be increasingly accommodated by axial magmatic emplacement without appreciable crustal thinning, which again modify the stress field to focus subsequent magmatic injections in the same area (Buck, 2006; Beutel et al., 2010; Bastow et al., 2011). Initial faulting may have been on detachment faults, but later deformation of the lithosphere has become symmetric, and shear wave splitting shows rift-parallel magmatic diking into the lithosphere under the rift zone (Kendall et al., 2005). Upper mantle body-wave low-velocity anomalies are among the largest observed and indicate a very hot mantle, possibly with some partial melt (Bastow et al., 2008). Present extension rate within the main Ethiopian Rift is about 4-7 $\mathrm{mm} \mathrm{y}^{-1}$, mostly located to a $\sim 30 \mathrm{~km}$ wide zone (Bastow et al., 2011). This indicates low strain rates of $4.2 \cdot 10^{-15} \mathrm{~s}^{-1}$ to $7.4 \cdot 10^{-15} \mathrm{~s}^{-1}$, which are close to that observed on the Iberian Margin. It thus appears that it is the elevated mantle temperature that produces magmatism here, despite the low strain rate. This development will eventually produce the typical volcanic margin architecture, with low crustal stretching, lower-crustal magmatic intrusions, and both extensive pre- and post-breakup magmatism.

The examples described above are end-members of passive rifted margin formation, from magma-starved to magma-rich. Ongoing rifting in the Woodlark Basin off Papua New Guinea is creating a rifted margin intermediate between these. Sedimentation is low, and the crustal struc- 
ture is easily observed on high-resolution bathymetry and reflection seismic data (Taylor et al., 1995). The margin is characterized by both steep and low-angle faults, both of which can facilitate crustal breakup (Taylor et al., 1999). The Moresby seamount is a metamorphic core complex developing on a low-angle detachment. The continent-ocean transition zone is well defined and less than $5 \mathrm{~km}$ wide, and no dipping reflector sequences are observed that would indicate elevated magmatism. Minor continental magmatism is observed along some faults, where $\mathrm{Na}_{8.0}$ data show a low mantle melt degree (Taylor et al., 1995). As seafloor spreading and progressive rifting occurs contemporaneously, early seafloor spreading rates in the east can be used to determine strain rates in western parts of the margin still extending, similar to our approach. Central parts have the highest rates; $1.5-2.6 \cdot 10^{-14} \mathrm{~s}^{-1}$ (Taylor et al., 1999), which are about half of that observed in our study area.

The Lofoten/Vesterålen Margin resemble most the passive margins of the Woodlark Basin, with its high strain rate, low magmatism, and low-angle detachment faults. If the asthenosphere underneath had significantly elevated temperature, even a low strain rate should produce excess magmatism at an early stage as seen in the East African Rift System. However, the estimated strain rate is expected to produce normal oceanic crust from the time of crustal separation, and not sub-continental mantle unroofing and serpentinization. Clearly, the extension did not produce magmatism until very late, resulting in strongly thinned crust and delayed continental breakup. Nevertheless, the $8 \mathrm{~km}$ thick oceanic crust, as well as the lower-crustal igneous intrusions seen locally, show a slightly elevated magma production. Excess magmatism died down to a $6 \mathrm{~km}$ thick oceanic crust already 1 m.y. after breakup, demonstrating a limited plume reservoir. While plume material was present at the Vøring Plateau before breakup (Skogseid et al., 2000), it must have reached the Lofoten/Vesterålen Margin later and in lesser quantity. Buoyant plume material is expected to flow into the base lithospheric topography (Sleep, 1997), and early seafloor spreading at the Vøring Plateau shows signs of active flow of plume material into the spreading zone for the first 2 m.y. (Breivik et al., 2014). The abrupt bathymetric termination of the Vøring Plateau to the northeast suggests that magmatism was much reduced over a short distance (Fig. 2). Once seafloor spreading starts, lateral plume flow will be inhibited by melt/volatile extraction, leading to cooling and reduced buoyancy, as well as increased viscosity (Nielsen et al., 2002). Only the limited plume 
material already present nearby will flow into the rift zone at the Lofoten/Vesterålen Margin after breakup at the Vøring Plateau. That could explain the observed character of this margin, located at the boundary of the Iceland Plume influence.

\section{Summary and Conclusions}

Here we present a seismic model across a NW-SE oriented profile over the inner Lofoten archipelago and the outer continental margin based on ocean bottom seismometers and land stations. It shows a strongly reflective layer boundary at $14-15 \mathrm{~km}$ depth beneath Vestfjorden and the mainland coastal areas. The velocity is low down to this level $\left(\sim 6.0-6.3 \mathrm{~km} \mathrm{~s}^{-1}\right)$, and the reflector likely represents the bottom of a large Paleoproterozoic granitoid within the Trans-Scandinavian Igneous Belt (Olesen et al., 2002; Gradmann and Ebbing, 2015). Crustal thickness is up to $36 \mathrm{~km}$ underneath Lofoten here, which is significantly thicker than what earlier studies nearby suggested (Sellevoll, 1983; Mjelde et al., 1996). Low upper-crustal velocities (5.8-5.9 $\mathrm{km} \mathrm{s}^{-1}$ ) at the inner Lofoten show a felsic lithology, consistent with low gravity anomalies. The northern Utrøst Ridge (Jennegga High) has higher velocities than the surrounding areas, with $6.3 \mathrm{~km} \mathrm{~s}^{-1}$ from top basement to $6.7 \mathrm{~km} \mathrm{~s}^{-1}$ at mid-crustal levels. It may be connected to a $\sim 6.8-6.9 \mathrm{~km} \mathrm{~s}^{-1}$ lower-crustal layer sloping eastwards with a highly reflective top and eastern side.

There is little evidence of the proposed lava flows (Talwani et al., 1983; Tsikalas et al., 2001) at the outer margin this far north. Strong reflectivity and mounds previously interpreted as lavas may have both a sedimentary and tectonic origin. Post-breakup sediments from the shelf have quite high velocities at our profile, while distal, fine-grained turbidites from the Barents Sea (Hjelstuen et al., 2007) have significantly lower velocities, and could produce a good reflector where these overlap. Mounds are related to mass wasting off the shelf in the northern part of the margin (Rise et al., 2013). Higher up on the continental slope, post-breakup sediments appear to rest on a fault surface exposing well-consolidated pre-breakup sedimentary rocks, apparently also a good reflector in the area (Tasrianto and Escalona, 2015).

The sedimentary rocks of the outer margin are divided into two layers, interpreted as Cretaceous for the upper and Early Cretaceous and/or older for the lower. The top of the lower layer has high topography consistent with large rotated fault blocks. Low-angle detachment faults soling 
out in a ductile lower crust can explain the geometry. The heave of the two inner detachments then indicate a minimum extension of $26-30 \mathrm{~km}$. The basement of the outer margin has low velocities (6.0-6.4 $\mathrm{km} \mathrm{s}^{-1}$ ) and a minimum thickness of $4.5 \mathrm{~km}$, with a smooth structure consistent with ductile deformation. There is an up to $3.5 \mathrm{~km}$ thick $6.9-7.1 \mathrm{~km} \mathrm{~s}^{-1}$ velocity layer at the bottom of the crust at the outermost margin, which extends $\sim 50 \mathrm{~km}$ landward. The velocity is consistent with breakup-related magmatic intrusion of the lower continental crust usually observed at volcanic margins. This is the first identification of such a feature of the Lofoten/Vesterålen margin, but it is smaller than that typically seen on volcanic margins. The earliest oceanic crust shows only moderately elevated post-breakup magmatism; it is $8 \mathrm{~km}$ thick adjacent to the continent, and is reduced to $6 \mathrm{~km}$ already after $1 \mathrm{~m} . \mathrm{y}$. of seafloor spreading.

The ship magnetic profile was used to determine early seafloor spreading rates. These agree with results from the Norway Basin (Breivik et al., 2006, 2012) and the northern Vøring Plateau (Breivik et al., 2009), but apparently deviates for the earliest phase. Plate spreading rate should be similar for nearby margin segments, and forward modeling using established rates could only reproduce the observed magnetic anomalies if breakup occurred at 53.1 Ma (Cande and Kent, 1995). This is at least 1 m.y. later than at the Norwegian margin to the south. An extra 1 m.y. of stretching at a rate of $30 \mathrm{~mm} \mathrm{y}^{-1}$ can explain $30 \mathrm{~km}$ of additional extension of the outer margin, indicating that the detachment faults developed during this phase. That would imply a strain rate of $\sim 3.2 \cdot 10^{-14} \mathrm{~s}^{-1}$

With such a high strain-rate, magmatic diking of the lithosphere should rapidly become the dominant extension process if the asthenosphere was unusually hot (Buck, 2006), and cause an earlier breakup coeval with the rest of the margin. Plume material was probably not present at the margin until close to breakup time, and then in moderate quantity. Seafloor spreading on the Vøring Plateau to the south should inhibit northwards flow from the Iceland Plume (Nielsen et al., 2002). However, plume material already ponded underneath thin lithosphere nearby (e.g., Sleep, 1997), could have flowed into the rift zone at the Lofoten/Vesterålen Margin. That could explain a late arrival of a small amount of plume material, resulting in both initial magma-starved extension, and a subsequent short-lived and only moderately elevated breakup magmatism which tapers off northwards 


\section{References}

Armitage, J. J., Collier, J. S., Minshull, T. A., 2010. The importance of rift history for volcanic margin formation. Nature 465, 913-917.

Bastow, I., Keir, D., Daly, E., 2011. The Ethiopia Afar Geoscientific Lithospheric Experiment (EAGLE): Probing the transition from continental rifting to incipient seafloor spreading. In: Beccaluva, L., Bianchini, G., Wilson, M. (Eds.), Volcanism and Evolution of the African Lithosphere. No. 478. Geol. Soc. Am. Spec. Pap., Boulder, pp. 51-76.

Bastow, I. D., Nyblade, A. A., Stuart, G. W., Rooney, T. O., Benoit, M. H., 2008. Upper mantle seismic structure beneath the Ethiopian hot spot: Rifting at the edge of the African low-velocity anomaly. Geochem., Geophys., Geosyst. 9 (12)

Bergh, S. G., Eig, K., Kløvjan, O. S., Henningsen, T., Olesen, O., Hansen, J. A., 2007. The Lofoten-Vesterålen continental margin: a multiphase Mesozoic-Palaeogene rifted shelf as shown by offshore-onshore brittle faultfracture analysis. Norw. J. Geol. 87, 29-58.

Berndt, C., Planke, S., Alvestad, E., Tsikalas, F., Rasmussen, T., 2001. Seismic volcanostratigraphy of the Norwegian Margin: constraints on tectonomagmatic break-up processes. J. Geol. Soc. 158, 413-426.

Berndt, C., Skogly, O. P., Planke, S., Eldholm, O., December 2000. High-velocity breakup-related sills in the Vøring Basin, off Norway. J. Geophys. Res. 105 (B12), 28443-28454.

Beutel, E., van Wijk, J., Ebinger, C., Keir, D., Agostini, A., 2010. Formation and stability of magmatic segments in the Main Ethiopian and Afar rifts. Earth Planet. Sci. Lett. 293 (3), 225-235.

Breivik, A., Mjelde, R., Faleide, J. I., Flueh, E., Murai, Y., 2014. Magmatic development of the outer Vøring margin from seismic data. J. Geophys. Res. 119, 6733-6755.

Breivik, A. J., Faleide, J. I., Gudlaugsson, S. T., 1998. Southwestern Barents Sea margin: late Mesozoic sedimentary basins and crustal extension. Tectonophysics 293, 21-44.

Breivik, A. J., Faleide, J. I., Mjelde, R., Flueh, R., 2009. Magma productivity and early seafloor spreading rate correlation on the northern Vøring Margin, Norway - Constraints on mantle melting. Tectonophysics 468, 206223.

Breivik, A. J., Mjelde, R., Faleide, J. I., Murai, Y., 2006. Rates of continental breakup magmatism and seafloor spreading in the Norway Basin - Iceland plume interaction. J. Geophys. Res. 111 (B07102).

Breivik, A. J., Mjelde, R., Faleide, J. I., Murai, Y., 2012. The eastern Jan Mayen microcontinent volcanic margin. Geophys. J. Int. 188, 798-818.

Brekke, H., 2000. The tectonic evolution of the Norwegian Sea Continental Margin with emphasis on the Vøring and Møre Basins. In: Nøttvedt, A., Larsen, B. T., Olaussen, S., Tørudbakken, B., Skogseid, J., Gabrielsen, R. H., Brekke, H., Birkeland, Ø. (Eds.), Dynamics of the Norwegian Margin. Vol. 167. Geol. Soc. Spec. Publ., London, U.K., pp. 327-378. 
Buck, W. R., 2006. The role of magma in the development of the Afro-Arabian Rift system. In: Yirgu, G., Ebinger, C. J., Maguire, P. K. H. (Eds.), The Afar Volcanic Province within the East African Rift System. Vol. 259. Geol. Soc. Spec. Publ., London, U.K., pp. 43-54.

Cande, S. C., Kent, D. V., 1995. Revised calibration of the geomagnetic polarity time scale for Late Cretaceous and Cenozoic. J. Geophys. Res. 100 (B4), 6093-6095.

Chian, D., Louden, K. E., Minshull, T. A., Whitmarsh, R. B., 1999. Deep structure of the ocean-continent transition in the southern Iberia Abyssal Plain from seismic refraction profiles: Ocean Drilling Program (Legs 149 and 173) transect. J. Geophys. Res. 104 (B4), 7443-7462.

Christensen, N. I., Mooney, W. D., 1995. Seismic velocity structure and composition of continental crust: A global view. J. Geophys. Res. 100 (B7), 9761-9788.

Chroston, P. N., Brooks, S. G., 1989. Lower crustal seismic velocities from Lofoten-Vesterålen, north Norway. Tectonophysics 157, 251-269.

Ebbing, J., Gernigon, L., Pascal, C., Olesen, O., Osmundsen, P. T., 2009. A discussion of structural and thermal control of magnetic anomalies on the mid-Norwegian margin. Geophys. Prosp. 57, 665-681.

Eldholm, O., Coffin, M. F., 2000. Large igneous provinces and plate tectonics. In: Richards, M. A., Gordon, R. G., van der Hilst, R. D. (Eds.), The history and dynamics of global plate motions. Vol. 121 of Geophys. Monogr. Am. Geophys. Un., Washington, DC, pp. 309-326.

Eldholm, O., Grue, K., 1994. North Atlantic volcanic margins: Dimensions and production rates. J. Geophys. Res. 99 (B2), 2955-2968.

Eldholm, O., Skogseid, J., Planke, S., Gladczenko, T. P., 1995. Volcanic margin concepts. In: Banda, E., Talwani, M., Torne, M. (Eds.), Rifted Ocean-Continent Boundaries: NATO ASI Series Volume. pp. 1-16.

Færseth, R. B., 2012. Structural development of the continental shelf offshore Lofoten-Vesterålen, northern Norway. Norw. J. Geol. 92, 19-40.

Gaina, C., Gernigon, L., Ball, P., 2009. Palaeocene-Recent plate boundaries in the NE Atlantic and the formation of the Jan Mayen microcontinent. J. Geol. Soc. 166, 601-616.

Gernigon, L., Ringenbach, J.-C., Planke, S., Le Gall, B., 2004. Deep structures and breakup along volcanic rifted margins: insights from integrated studies along the outer Vøring Basin (Norway). Mar. Petrol. Geol. 21, 363-372.

Gradmann, S., Ebbing, J., 2015. Large-scale gravity anomaly in northern Norway: tectonic implications of shallow or deep source depth and a possible conjugate in northeast Greenland. Geophys. J. Int. 203, 2070-2088.

Griffin, W. L., Taylor, P. N., Hakkinen, J. W., Heier, K. S., Iden, I. K., Krogh, E. J., Malm, O., Olsen, K. I., Ormaasen, D. E., Tveten, E., 1978. Archaean and Proterozoic crustal evolution in Lofoten-Vesterålen, N Norway. J. Geol. Soc. 135 (6), 629-647.

Hansen, J.-A., Bergh, S. G., Henningsen, T., 2012. Mesozoic rifting and basin evolution on the Lofoten and Vesterålen Margin, North-Norway; time constraints and regional implications. Norw. J. Geol. 91, 203-228. 
Hjelstuen, B. O., Eldholm, O., Faleide, J. I., 2007. Recurrent Pleistocene mega-failures on the SW Barents Sea margin. Earth Planet. Sci. Lett. 258, 605-618.

Holbrook, W. S., Larsen, H. C., Korenaga, J., Dahl-Jensen, T., Reid, I. D., Kelemen, P. B., Hopper, J. R., Kent, G. M., Lizarralde, D., Bernstein, S., Detrick, R. S., 2001. Mantle thermal structure and active upwelling during continental breakup in the North Atlantic. Earth Planet. Sci. Lett. 190, 251-266.

Hooft, E. E. E., Detrick, R. S., Toomey, D. R., Collins, J. A., Lin, J., 2000. Crustal thickness and structure along three contrasting spreading segments of the Mid- Atlantic Ridge, $33.5^{\circ}-35^{\circ}$ N. J. Geophys. Res. 105 (B4), 8205-8226.

Howell, S. M., Ito, G., Breivik, A. J., Rai, A., Mjelde, R., Hanan, B., Sayit, K., Vogt, P., 2014. The origin of the asymmetry in the Iceland hotspot along the Mid-Atlantic Ridge from continental breakup to present-day. Earth Planet. Sci. Lett. 392, 143-153.

Jakobsson, M., Mayer, L. A., Coakley, B., Dowdeswell, J. A., Forbes, S., Fridman, B., Hodnesdal, H., Noormets, R., Pedersen, R., Rebesco, M., Schenke, H.-W., Zarayskaya, Y., Accettella, A. D., Armstrong, A., Anderson, R. M., Bienhoff, P., Camerlenghi, A., Church, I., Edwards, M., Gardner, J. V., Hall, J. K., Hell, B., Hestvik, O. B., Kristoffersen, Y., Marcussen, C., Mohammad, R., Mosher, D., Nghiem, S. V., Pedrosa, M. T., Travaglini, P. G., P., W., 2012. International Bathymetric Chart of the Arctic Ocean (IBCAO) Version 3.0. Geophys. Res. Lett. 39 (L12609).

Kendall, J.-M., Stuart, G. W., Ebinger, C. J., Bastow, I. D., Keir, D., 2005. Magma-assisted rifting in Ethiopia. Nature $433,146-148$.

Kodaira, S., Goldschmidt-Rokita, A., Hartman, J. M., Hirschleber, H. B., Iwasaki, T., Kanazawa, T., Krahn, H., Tomita, S., Shimamura, H., 1995. Crustal structure of the Lofoten continental margin, off northern Norway, from ocean-bottom seismographic studies. Geophys. J. Int. 121, 907-924.

Kusznir, N. J., Park, R. G., 1987. The extensional strength of the continental lithosphere: its dependence on geothermal gradient, and crustal composition and thickness. In: Coward, M. P., D. J. F., Hancock, P. L. (Eds.), Continental Extensional Tectonics. Vol. 28. Geol. Soc., London, Spec. Publ., pp. 35-52.

Lawver, L. A., Müller, R. D., 1994. Iceland hotspot track. Geology 22, 311-314.

Løseth, H., Tveten, E., 1996. Post-Caledonian structural evolution of the Lofoten and Vesterålen offshore and onshore areas. Norsk Geol. Tidsskr. 76, 215-230.

Mihalffy, P., Steinberger, B., Schmeling, H., 2008. The effect of the large-scale mantle flow field on the Iceland hotspot track. Tectonophysics 447 (1), 5-18.

Mjelde, R., Digranes, P., van Schaack, M., Shimamura, H., Shiobara, H. Kodaira, S., Naess, O., Sørenes, N., Vågnes, E., 2001. Crustal structure of the outer Vøring Plateau, offshore Norway, from ocean bottom seismic and gravity data. J. Geophys. Res. 106 (B4), 6769-6791.

Mjelde, R., Faleide, J. I., Breivik, A. J., Raum, T., 2009. Lower crustal composition and crustal lineaments on the Vøring Margin, NE Atlantic: A review. Tectonophysics 427, 183-193. 
Mjelde, R., Kodaira, S., Sellevoll, M. A., 1996. Crustal structure of the Lofoten Margin, N. Norway from normal incidence and wide-angle seismic data: a review. Nor. Geol. Tidsskr. 76, 187-198.

Mjelde, R., Raum, T., Breivik, A., Shimamura, H., Murai, Y., Takanami, T., Faleide, J. I., 2005a. Crustal structure of the Vøring Margin, NE Atlantic: a review of geological implications based on recent OBS data. In: Doré, A. G., Vining, B. A. (Eds.), Petroleum Geology: North-West Europe and Global Perspectives - Proceedings of the 6th Petroleum Geology Conference. Geol. Soc., London, pp. 803-814.

Mjelde, R., Raum, T., Myhren, B., Shimamura, H., Murai, Y., Takanami, T., Karpuz, R., Næss, U., 2005b. Continentocean transition on the Vøring Plateau, NE Atlantic, derived from densely sampled ocean bottom seismometer data. J. Geophys. Res. 110.

Mjelde, R., Sellevoll, M. A., Shimamura, H., Iwasaki, T., Kanazawa, T., 1992. A crustal study off Lofoten, N. Norway by use of 3-C ocean bottom seismographs. Tectonophysics 212, 269-288.

Mjelde, R., Sellevoll, M. A., Shimamura, H., Iwasaki, T., Kanazawa, T., 1993. Ocean Bottom Seismographs used in a crustal study of an area covered with flood-basalt off Lofoten, N. Norway. Terra Nova 5, 76-84.

Mjelde, R., Timenes, T., Shimamura, H., Kanazawa, T., Shiobara, H., Kodaira, S., Nakanishi, A., 2002. Acquisition, processing and analysis of densely sampled P- and S-wave OBS-data on the mid-Norwegian Margin, NE Atlantic. Earth Planets Space 54, 1219-1236.

Mokhtari, M., Pegrum, R. M., 1992. Structure and evolution of the Lofoten continental margin, offshore Norway. Nor. Geol. Tidsskr. 72, 339-355.

Mosar, J., Lewis, G., Torsvik, T. H., 2002. North Atlantic sea-floor spreading rates: implications of the Tertiary development of inversion structures of the Norwegian-Greenland Sea. J. Geol. Soc. 159, 503-515.

Mutter, J. C., Zehnder, C. M., 1988. Deep crustal structure and magmatic processes: the inception of seafloor spreading in the Norwegian- Greenland Sea. In: Morton, A. C., Parsons, L. M. (Eds.), Early Tertiary volcanism and opening of the NE Atlantic. No. 39. Geol. Soc. Spec. Publ., London, U.K., pp. 35-48.

Nielsen, T. K., Larsen, H. C., Hopper, J. R., 2002. Contrasting rifted margin styles south of Greenland: implications for mantle plume dynamics. E. Planet. Sci. Lett. 200, 271-286.

Noble, R. H., Macintyre, R. M., Brown, P. E., 1988. Age constraints on Atlantic evolution: timing of magmatic activity along the E Greenland continental margin. Geol. Soc. Spec. Publ. 39, 201-214.

Ogg, J. G., 2012. Chaper 5: Geomagnetic polarity time scale. In: Gradstein, F. M., Ogg, J. G., Schmitz, M., Ogg, G. (Eds.), The geologic time scale 2012 2-volume set. Elsevier, pp. 85-112.

Olesen, O., Ebbing, J., Lundin, E., Mauring, E., Skilbrei, J. R., Torsvik, T. H., Hansen, E. K., Henningsen, T., Midbøe, P., Sand, M., 2007. An improved tectonic model for the Eocene opening of the Norwegian-Greenland Sea: Use of modern magnetic data. Mar. Petrol. Geol. 24, 53-66.

Olesen, O., Gellein, J., Gernigon, L., Kihle, O., Koziel, J., Lauritsen, T., Mogaard, J. O., Myklebust, R., Skilbrei, J. R., Usov, S., 2010. Magnetic anomaly map, Norway and adjacent areas, 1:3 million. 
Olesen, O., Lundin, E., Nordgulen, Ø., Osmundsen, P. T., Skilbrei, J. R., Smethurst, M. A., Solli, A., Bugge, T., Fichler, C., 2002. Bridging the gap between the onshore and offshore geology in Nordland, northern Norway. Norw. J. Geol. 82, 243-262.

Ormaasen, D. E., 1977. Petrology of the Hopen mangerite-charnockite intrusion, Lofoten, north Norway. Lithos 10, 291-310.

Osmundsen, P. T., Ebbing, J., 2008. Styles of extension offshore mid-Norway and implications for mechanisms of crustal thinning at passive margins. Tectonics 27, TC6016.

Pascal, C., Ebbing, J., Skilbrei, J., 2007. Interplay between the Scandes and the Trans-Scandinavian Igneous Belt: integrated thermo-rheological and potential field modelling of the Central Scandes profile. Norwegian J. Geol. 87, $3-12$.

Pérez-Gussinyé, M., Reston, T. J., March 2001. Rheological evolution during extension at nonvolcanic rifted margins: Onset of serpentinization and development of detachments leading to continental breakup. J. Geophys. Res. 106 (B3), 3961-3975.

Planke, S., Rasmussen, T., Rey, S. S., Myklebust, R., 2005. Seismic characteristics and distribution of volcanic intrusions and hydrothermal vent complexes in the Vøring and Møre basins. In: Doré, A. G., Vining, B. A. (Eds.), Petroleum Geology: North-West Europe and global perspectives - Proceedings of the 6th Petroleum Geology Conference. Geol. Soc., London, pp. 833-844.

Rabinowitz, P. D., LaBreque, J., 1979. The Mesozoic south Atlantic ocean and evolution of its continental margins. J. Geophys. Res. 84 (B11), 5973-6002.

Rise, L., Bøe, R., Riis, F., Bellec, V. K., Laberg, J. S., Eidvin, T., Elvenes, S., Thorsnes, T., 2013. The LofotenVesterålen continental margin, North Norway: canyons and mass-movement activity. Mar. Petr. Geol. 45, $134-149$. Saunders, A. D., Fitton, J. G., Kerr, A. C., Norry, M. J., Kent, R. W., 1997. The North Atlantic Igneous Province. In: Mahoney, J. J., Coffin, M. F. (Eds.), Large Igneous Provinces: Continental, Oceanic, and Planetary Flood Basalt Volcanism. Vol. 100 of Geophys. Monogr. Am. Geophys. Un., Washington, DC, pp. 45-93.

Schlinger, C. M., 1985. Magnetization of lower crust and interpretation of regional magnetic anomalies: example from Lofoten and Vesterålen, Norway. J. Geophys. Res. 90 (B13), 11484-11504.

Sellevoll, M. A., 1983. A study of the Earths crust in the island area of Lofoten-Vesterålen, northern Norway. Nor. Geol. Unders. Bull. 380, 235-243.

Skogseid, J., Planke, S., Faleide, J. I., Pedersen, T., Eldholm, O., Neverdal, F., 2000. NE Atlantic continental rifting and volcanic margin formation. In: Nøttvedt, A. (Ed.), Dynamics of the Norwegian margin. No. 167. Geol. Soc., Spec. Publ., London, pp. 295-326.

Sleep, N. H., 1997. Lateral flow and ponding of starting plume material. J. Geophys. Res. 102 (B5), 10001-10012.

Stab, M., Bellahsen, N., Pik, R., Quidelleur, X., Ayalew, D., Leroy, S., 2016. Modes of rifting in magma-rich settings: Tectono-magmatic evolution of Central Afar. Tectonics 35, 2-38. 
Talwani, M., Hinz, K., Mutter, J., 1983. Ocean continent boundary under the Norwegian continental margin. In: Bott, M. H. P., Saxov, S., Talwani, M. (Eds.), Structure and development of the Greenland- Scotland Ridge: New methods and concepts. Plenum Press, New York, pp. 121-131.

Tasrianto, R., Escalona, A., 2015. Rift architecture of the Lofoten-Vesterålen margin, offshore Norway. Mar. Petr. Geol. 64, 1-16.

Taylor, B., Goodliffe, A. M., Martinez, F., 1999. How continents break-up: Insights from Papua New Guinea. J. Geophys. Res. 104 (B4), 7497-7512.

Taylor, B., Goodliffe, A. M., Martinez, F., Hey, R., 1995. Continental rifting and initial sea-floor spreading in the woodlark basin. Nature 374, 534-537.

Thorsnes, T., Erikstad, L., Dolan, M. F. J., Bellec, V. K., 2009. Submarine landscapes along the Lofoten-VesterålenSenja margin, northern Norway. Norw. J. Geol. 89 (1), 5-16.

Thybo, H., Nielsen, C. A., 2009. Magma-compensated crustal thinning in continental rift zones. Nature 457, 873-876.

Torsvik, T. H., Van der Voo, R., Meert, J. G., Mosar, J., Walderhaug, H. J., 2001. Reconstructions of the continents around the North Atlantic at about the 60th parallel. Earth Planet. Sci. Lett. 187, 55-69.

Tsikalas, F., Faleide, J. I., Eldholm, O., 2001. Lateral variations in tectono-magmatic style along the LofotenVesterålen volcanic margin off Norway. Mar. Petrol. Geol. 18, 807-832.

Unternehr, P., Péron-Pinvidic, G., Manatschal, G., Sutra, E., 2010. Hyper-extended crust in the South Atlantic: in search of a model. Petrol. Geosci. 16, 207-215.

Vink, G. E., November 1984. A hotspot model for Iceland and the Vøring Plateau. J. Geophys. Res. 89 (B12), 99499959.

Voss, M., Jokat, W., 2007. Continent-ocean transition and voluminous magmatic underplating derived from P-wave velocity of the East Greenland continental margin. Geophys. J. Int. 170, 580-604.

Voss, M., Schmidt-Aursch, M. C., Jokat, W., 2009. Variations in magmatic processes along the East Greenland volcanic margin. Geophys. J. Int. 177, 755-782.

Wessel, P., Smith, W. H. F., 1991. Free software helps map and display data. Eos Trans. AGU 72, 441,445-446.

Wessel, P., Smith, W. H. F., Scharroo, R., Luis, J. F., Wobbe, F., 2013. Generic Mapping Tools: Improved version released. EOS Trans. AGU 94, 409-410.

White, R., McKenzie, D., 1989. Magmatism at rift zones: The generation of volcanic continental margins and flood basalts. J. Geophys. Res. 94 (B6), 7685-7729.

White, R., Spence, D., Fowler, S. R., McKenzie, D., Westbrook, G. K., Bowen, A., 1987. Magmatism at rifted continental margins. Nature 330, 439-444.

White, R. S., Smith, L. K., 2009. Crustal structure of the Hatton and the conjugate east Greenland rifted volcanic continental margins, NE Atlantic. J. Geophys. Res. 114 (B02305).

White, R. S., Smith, L. K., Roberts, A. W., Christie, P. A. F., Kusznir, N. J., iSIMM Team, 2008. Lower-crustal 


\section{Acknowledgments}

We thank H. Shimamura, O. Ritzmann, and A. Krabbenhöft for their invaluable participation in planning, executing, and initial processing of the OBS data, and C. Zelt for the forward/inversion seismic modeling software. Odleiv Olesen from the Geological Survey of Norway and Kajsa Hult from the Geological Survey of Sweden are thanked for providing gravity and magnetic grids. The first author would also like to thank Mike Coffin and Joanne Whittaker for organizing the stay at the Institute for Marine and Antarctic Studies (IMAS), University of Tasmania, Australia, where the main part of the paper was written. We would also like to thank the editor, an anonymous reviewer, and Bob White for their helpful reviews. The Research Council of Norway funded the wide-angle seismic survey under the European Science Foundation Euromargins program (CRP01). Additional funding was provided by the Large Scale Facility at GEOMAR, Project HPRI-CT-200100154. A.J. Breivik and J.I. Faleide acknowledge support from the Research Council of Norway through its Centres of Excellence funding scheme, project number 223272. The survey-specific data can be obtained by contacting authors A.J. Breivik or R. Mjelde. High-resolution topography/bathymetry is provided freely by the Norwegian Mapping Authority (www.kartverket.no). 
Table 1: Seismic model fit statistics for the major refracted phases and the Moho reflection, and a summary for all phases. Suffixes 1-3 indicate upper, middle, and lower crustal layers, while 4 indicates the lower crustal body at the margin. Suffix (h) indicates that the phase is modeled as a head wave. 'All phases' include reflections not tabulated.

\begin{tabular}{cccc}
\hline Phase & No. rays & RMS $\Delta \mathbf{t}(\mathbf{m s})$ & $\chi^{2}$ \\
\hline Water & 103 & 74 & 1.148 \\
$\mathrm{P}_{g 1}$ & 161 & 73 & 0.510 \\
$\mathrm{P}_{g 1(h)}$ & 341 & 106 & 1.544 \\
$\mathrm{P}_{g 2}$ & 541 & 113 & 1.081 \\
$\mathrm{P}_{g 3}$ & 255 & 107 & 0.531 \\
$\mathrm{P}_{g 4}$ & 34 & 143 & 0.941 \\
$\mathrm{P}_{n}$ & 388 & 92 & 0.434 \\
$\mathrm{P}_{n(h)}$ & 71 & 158 & 1.178 \\
$\mathrm{P}_{M} \mathrm{P}$ & 71 & 144 & 0.949 \\
All phases & 2879 & 116 & 0.950 \\
\hline
\end{tabular}



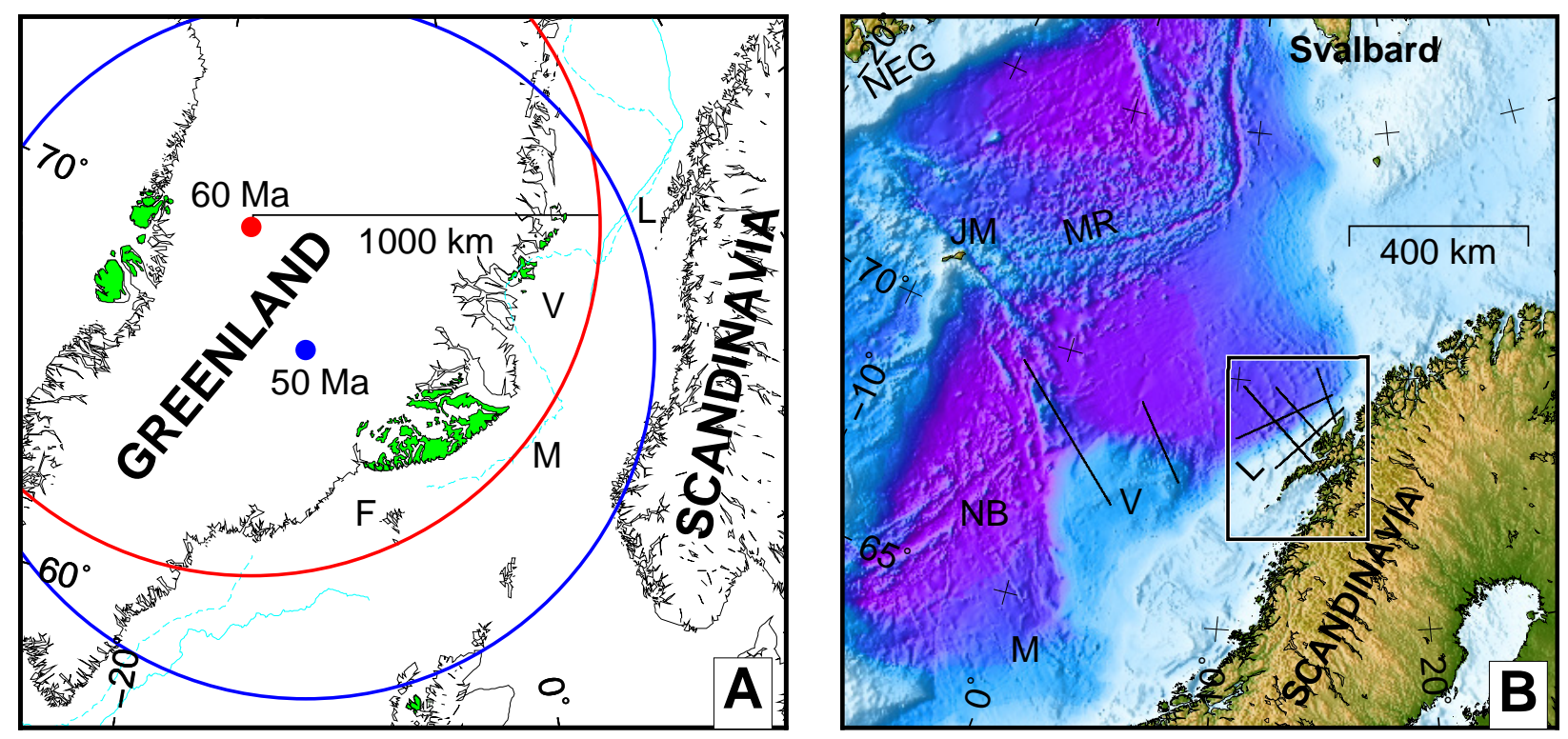

Figure 1: A: Continental reconstruction between Europe and Greenland back to opening based on spreading pole by Gaina et al. (2009). Green shading indicates early Cenozoic onshore flood basalts (Noble et al., 1988). The reconstructed $2000 \mathrm{~m}$ bathymetry contours are shown in cyan lines, solid from the Greenland side, and dashed from the Eurasian side. Iceland plume positions at $60 \mathrm{Ma}$ (red) and at $50 \mathrm{Ma}$ (blue) are from Lawver and Müller (1994), each enclosed by a $1000 \mathrm{~km}$ radius circle. B: Regional map with outline of study area (box) and seismic lines from the 2003 survey. See Fig. 2 for color scale. F: Faeroes, JM: Jan Mayen, L: Lofoten Margin, M: Møre Margin, MR: Mohn Ridge, NB: Norway Basin, NEG: North-East Greenland Margin V: Vøring Plateau. 


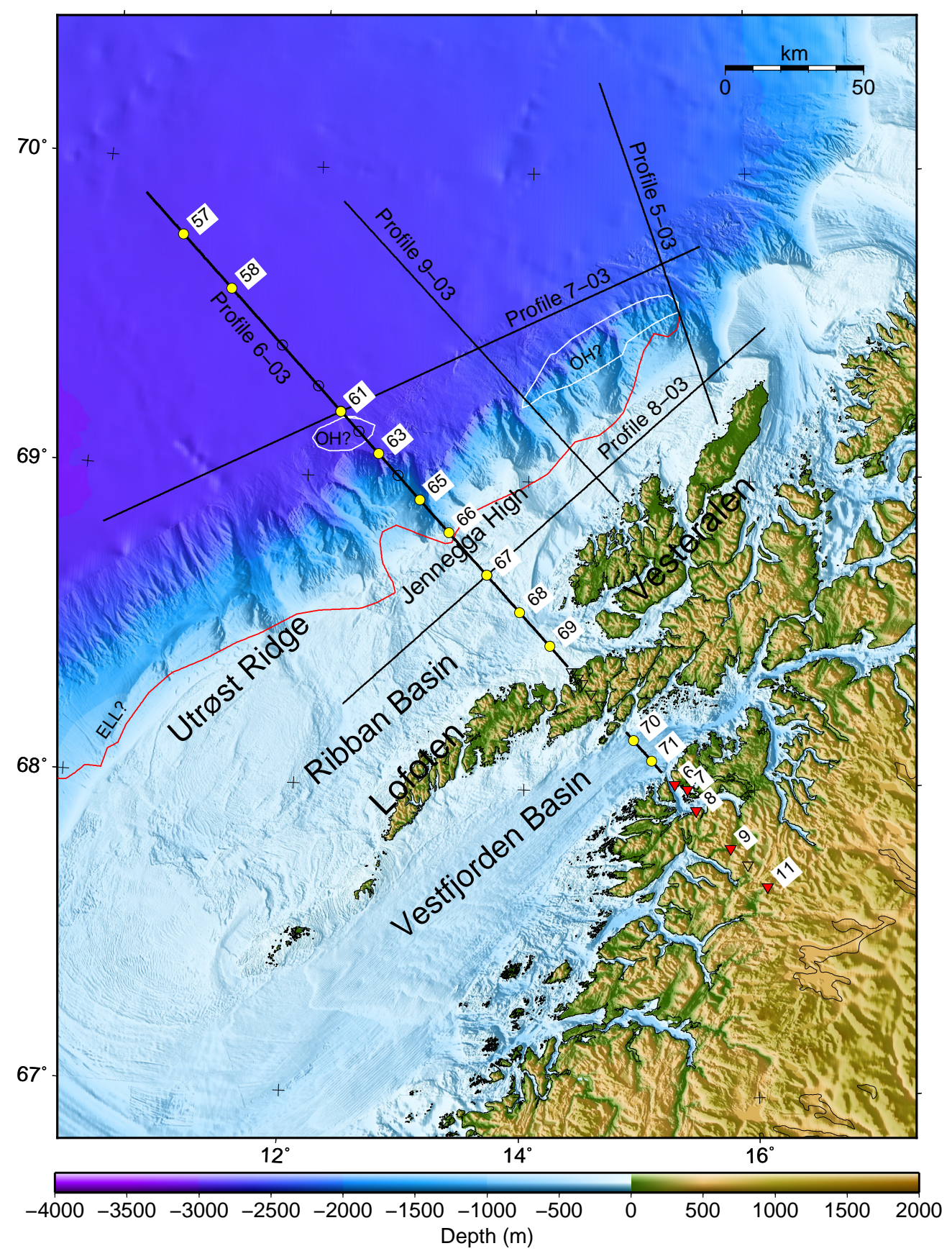

Figure 2: $200 \mathrm{~m}$ resolution topography and sidescan bathymetry based on $50 \mathrm{~m}$ resolution data from http://www.kartverket.no (C)Kartverket) with Euromargins 2003 OBS lines. Deep ocean bathymetry is IBCAO v.3 (Jakobsson et al., 2012). OBS positions on Profile 6 (bold, black line) are shown with yellow-filled circles, and land stations with red-filled, inverted triangles. Unfilled symbols mark failed stations. Red line shows the proposed eastern limit of lava (ELL?), and white lines outer volcanic highs (OH?) from Berndt et al. (2001). 

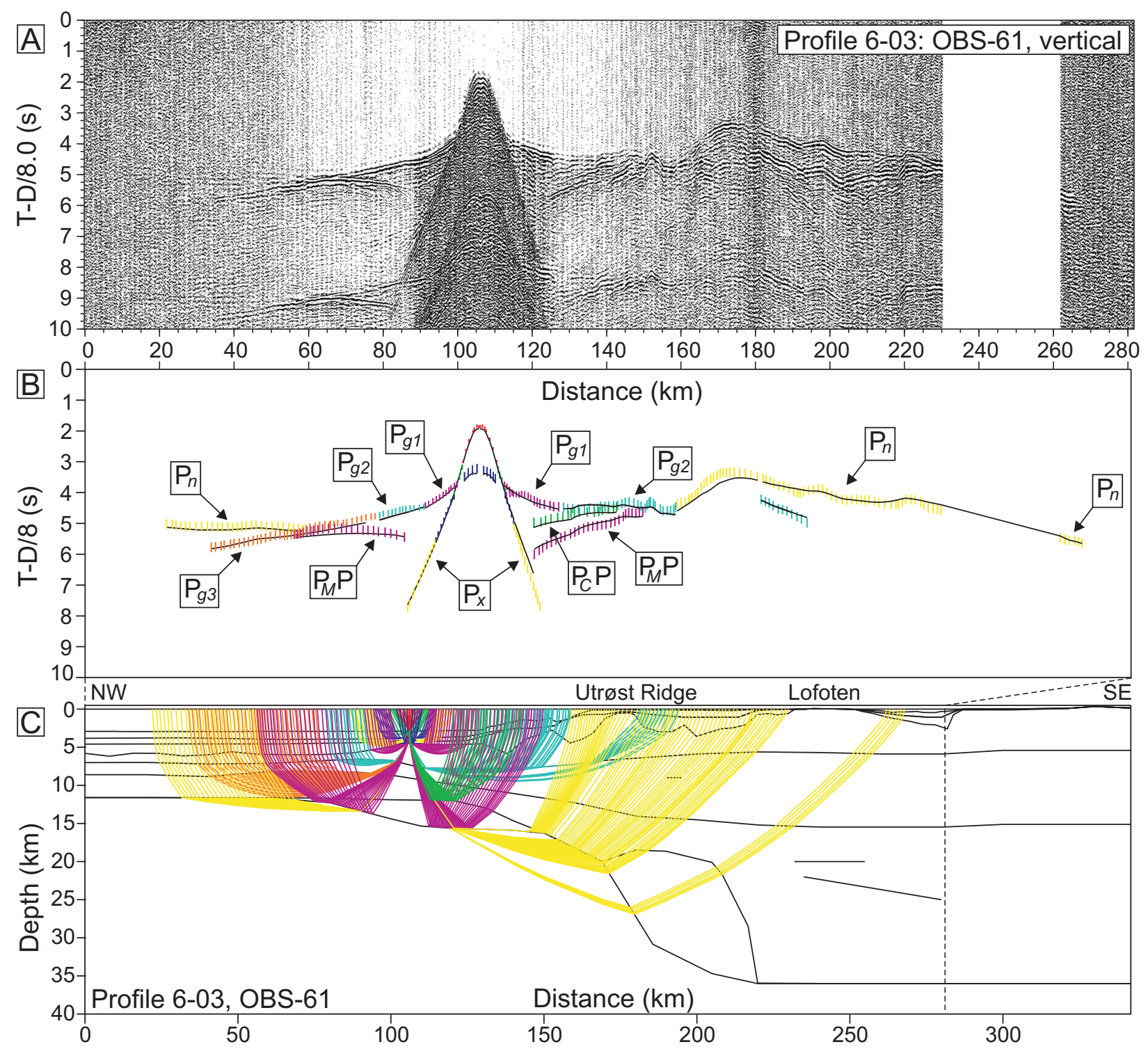

Figure 3: Data, interpretation, and ray tracing of OBS 61, Profile 6-03. A: OBS data, vertical component, offsetdependent scaling. B: Interpretation (vertical bars) and model prediction (solid lines). C: Ray tracing of the velocity model. 

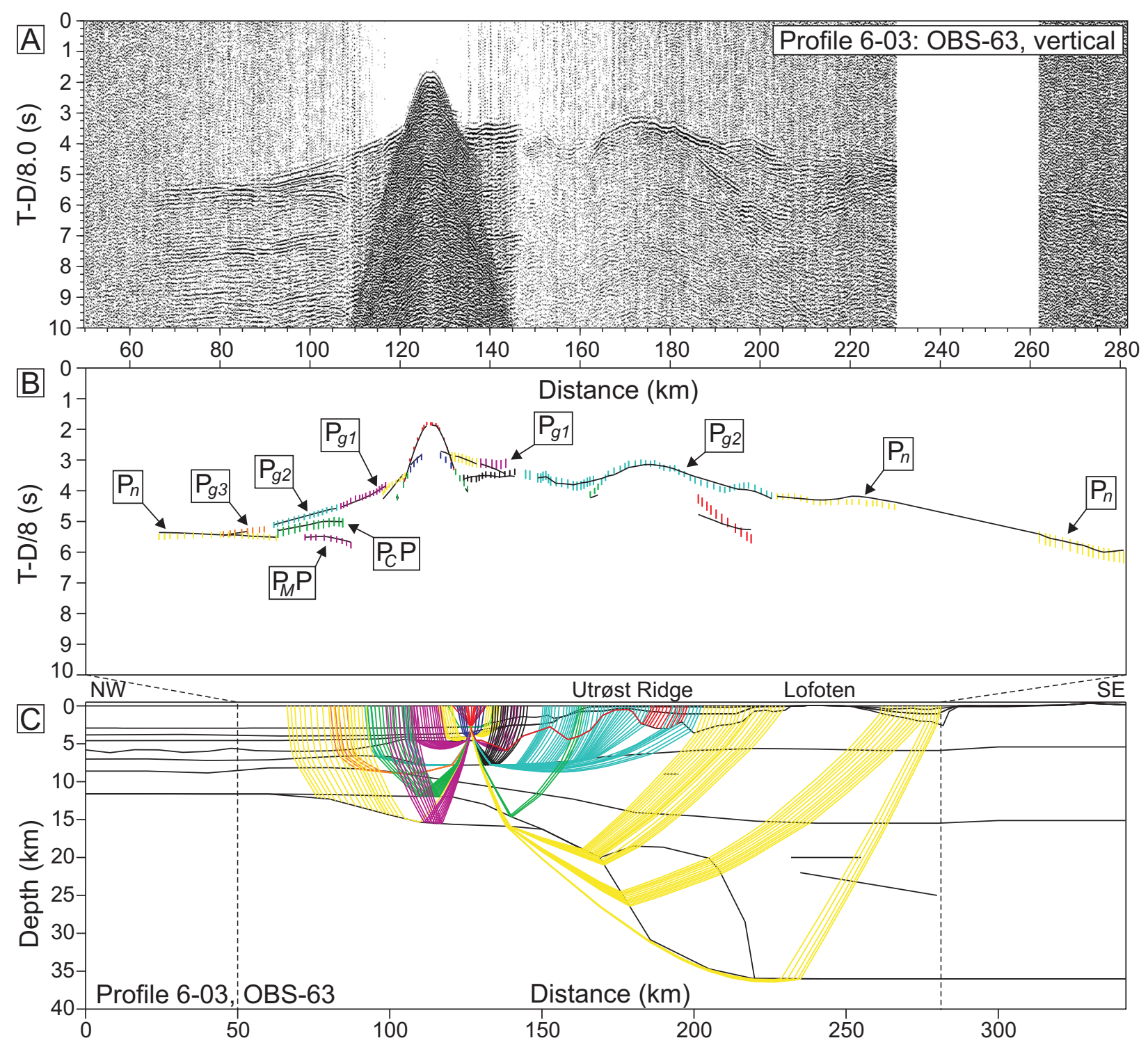

Figure 4: Data, interpretation, and ray tracing of OBS 63, Profile 6-03. A: OBS data, vertical component, offsetdependent scaling. B: Interpretation (vertical bars) and model prediction (solid lines). C: Ray tracing of the velocity model. 

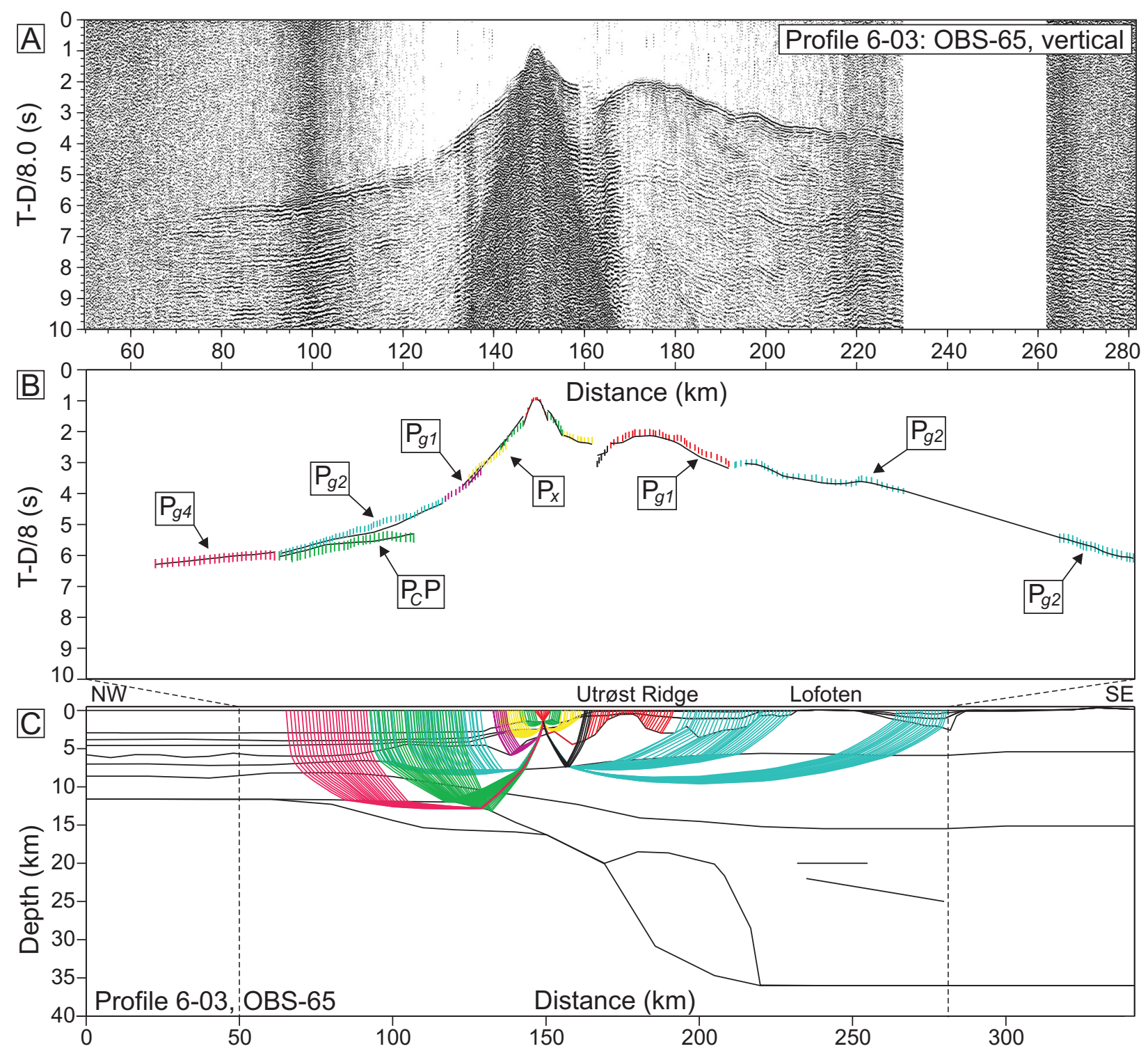

Figure 5: Data, interpretation, and ray tracing of OBS 65, Profile 6-03. A: OBS data, vertical component, offsetdependent scaling. B: Interpretation (vertical bars) and model prediction (solid lines). C: Ray tracing of the velocity model. 

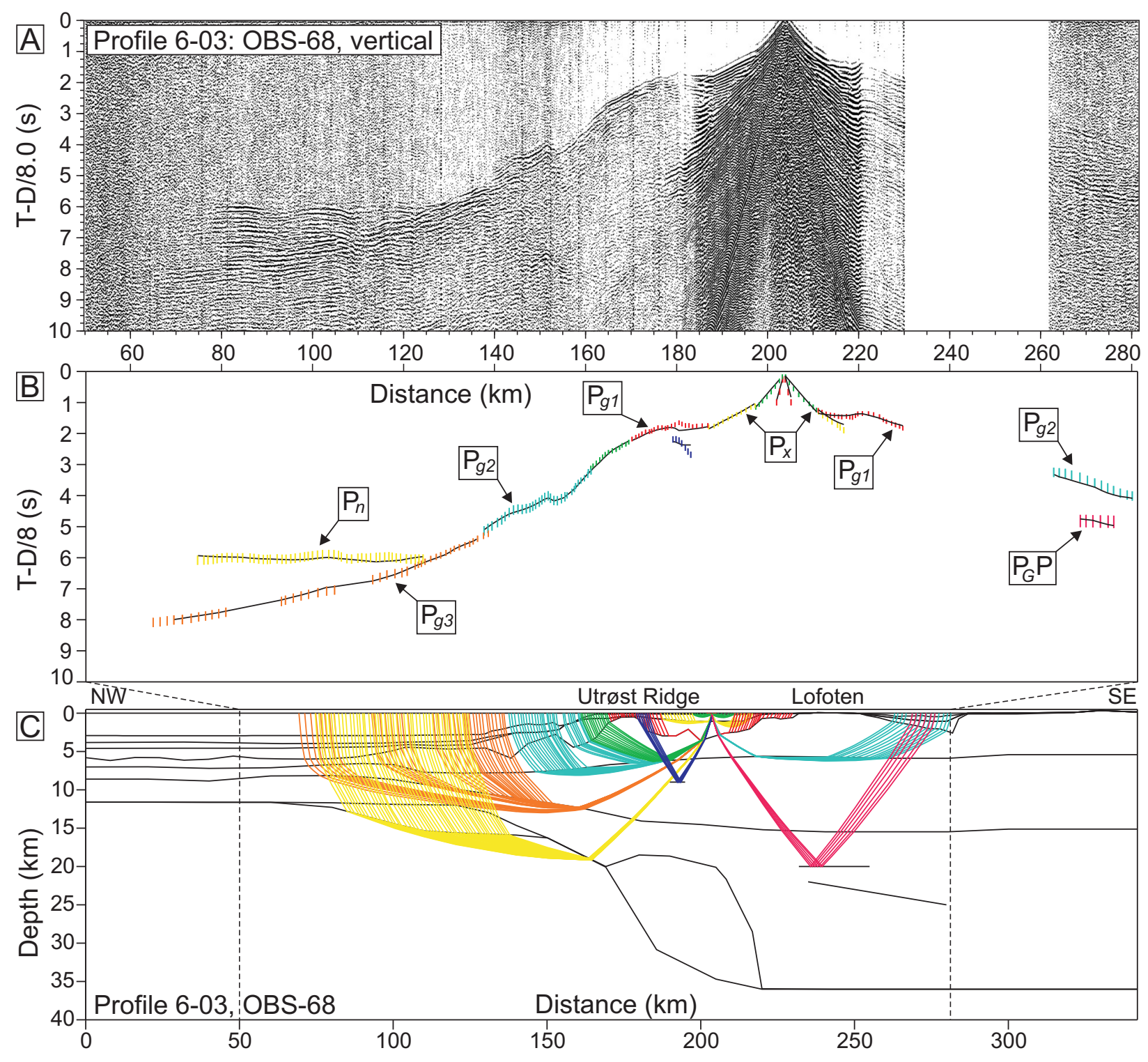

Figure 6: Data, interpretation, and ray tracing of OBS 68, Profile 6-03. A: OBS data, vertical component, offsetdependent scaling. B: Interpretation (vertical bars) and model prediction (solid lines). C: Ray tracing of the velocity model. 

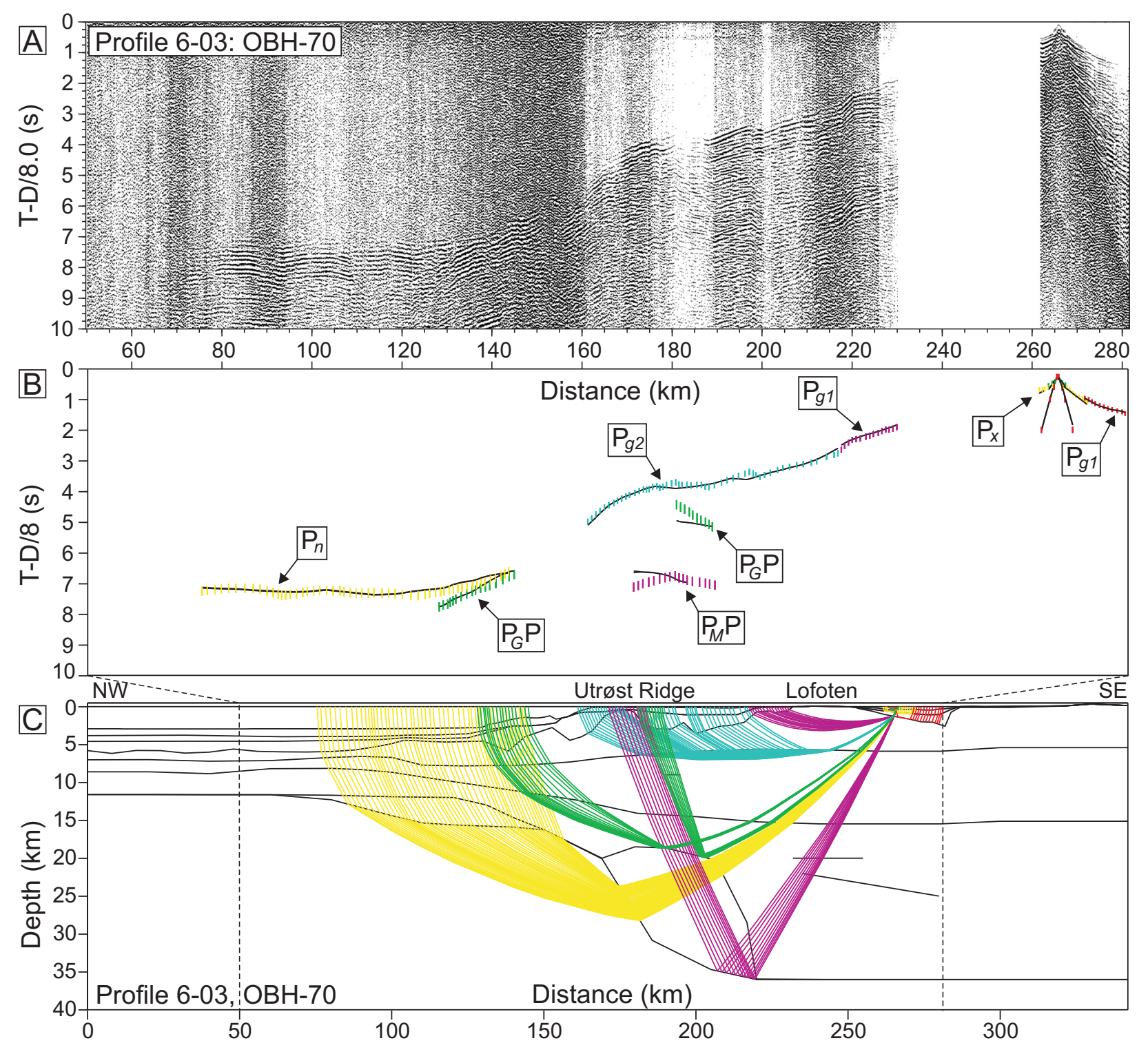

Figure 7: Data, interpretation, and ray tracing of OBH 70, Profile 6-03. A: Hydrophone data, offset-dependent scaling. B: Interpretation (vertical bars) and model prediction (solid lines). C: Ray tracing of the velocity model. 

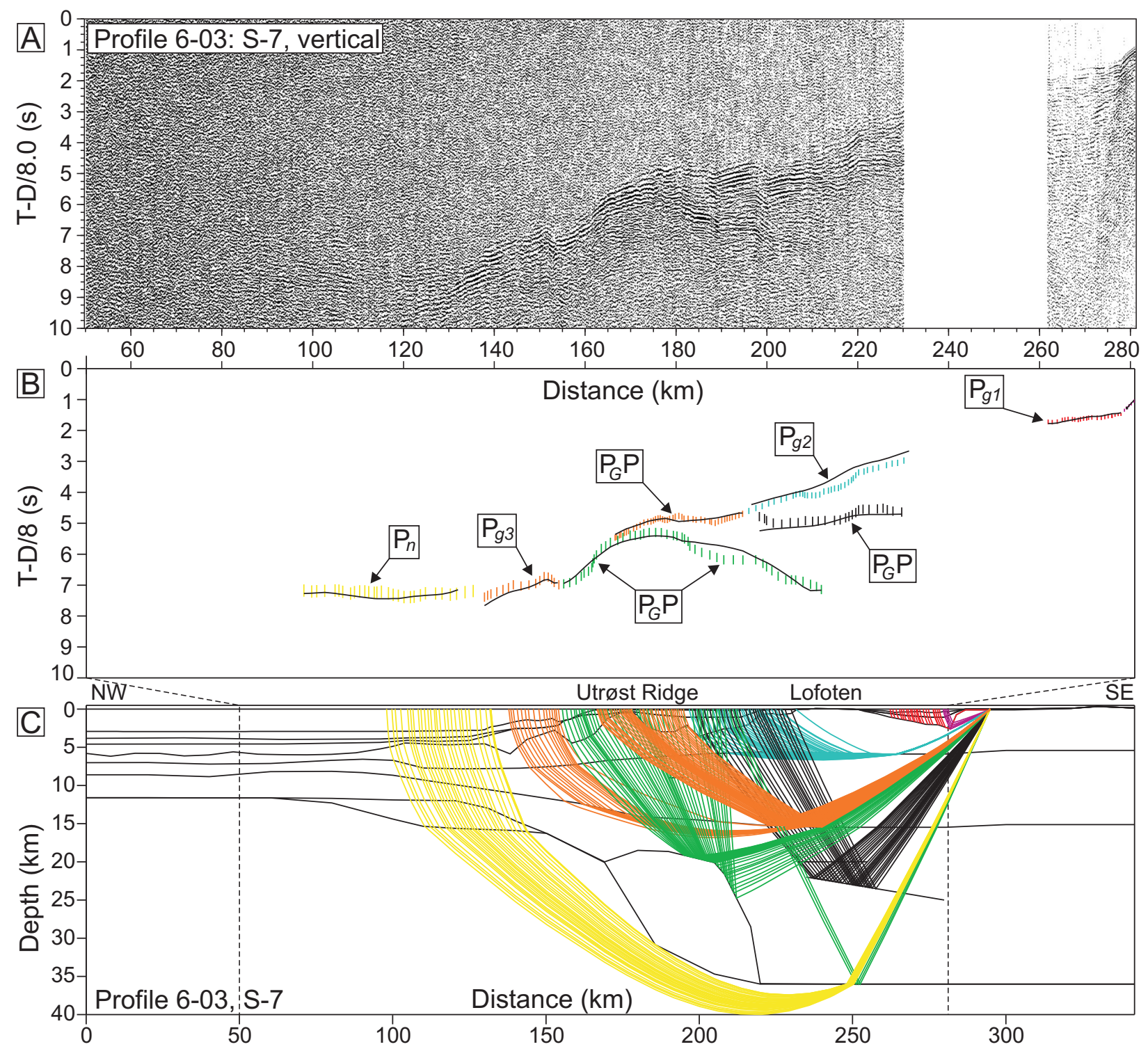

Figure 8: Data, interpretation, and ray tracing of land seismometer 7, Profile 6-03. A: Seismometer data, vertical component, offset-dependent scaling. B: Interpretation (vertical bars) and model prediction (solid lines). C: Ray tracing of the velocity model. 

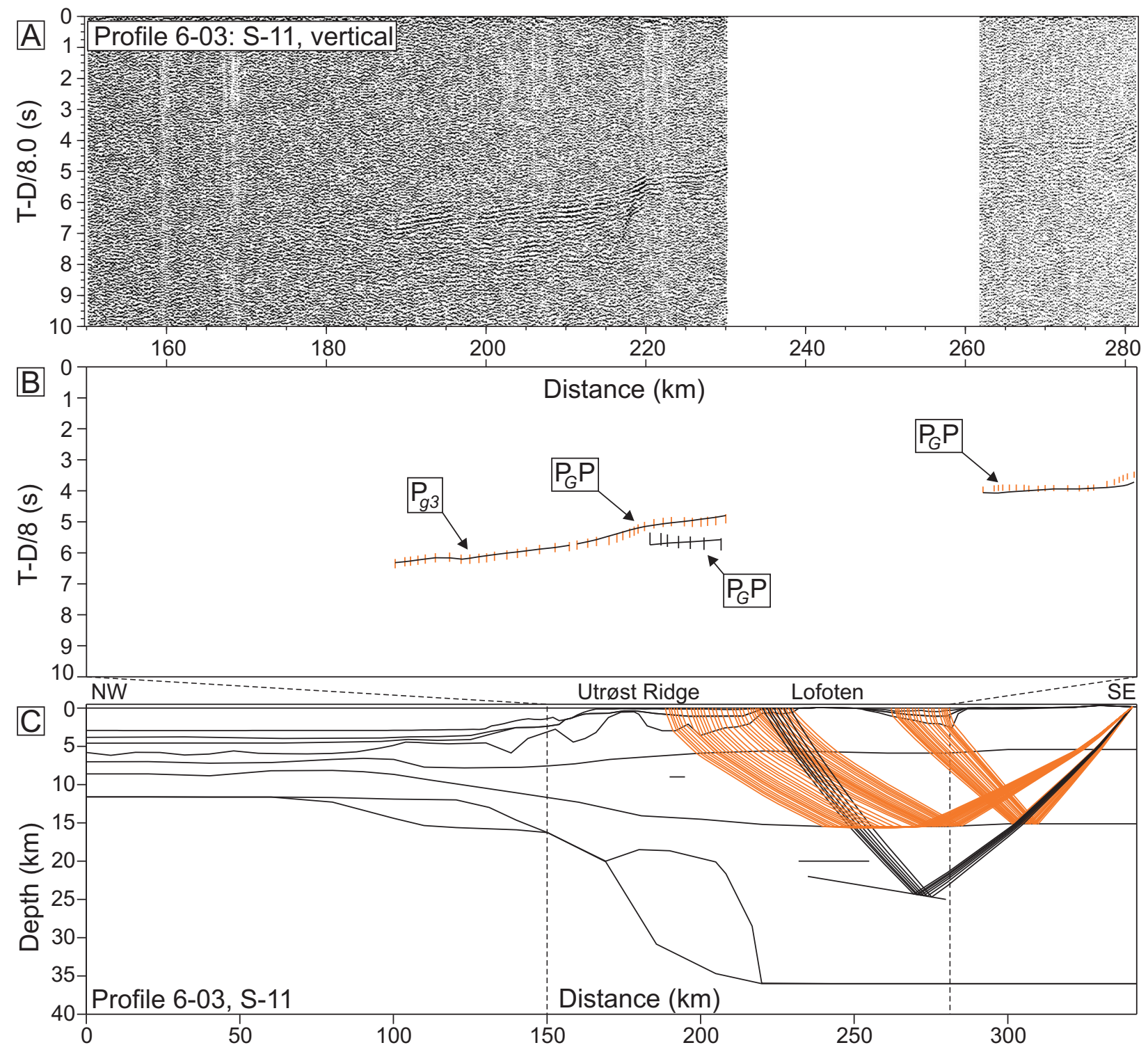

Figure 9: Data, interpretation, and ray tracing of land seismometer 11, Profile 6-03. A: Seismometer data, vertical component, offset-dependent scaling. B: Interpretation (vertical bars) and model prediction (solid lines). C: Ray tracing of the velocity model. 


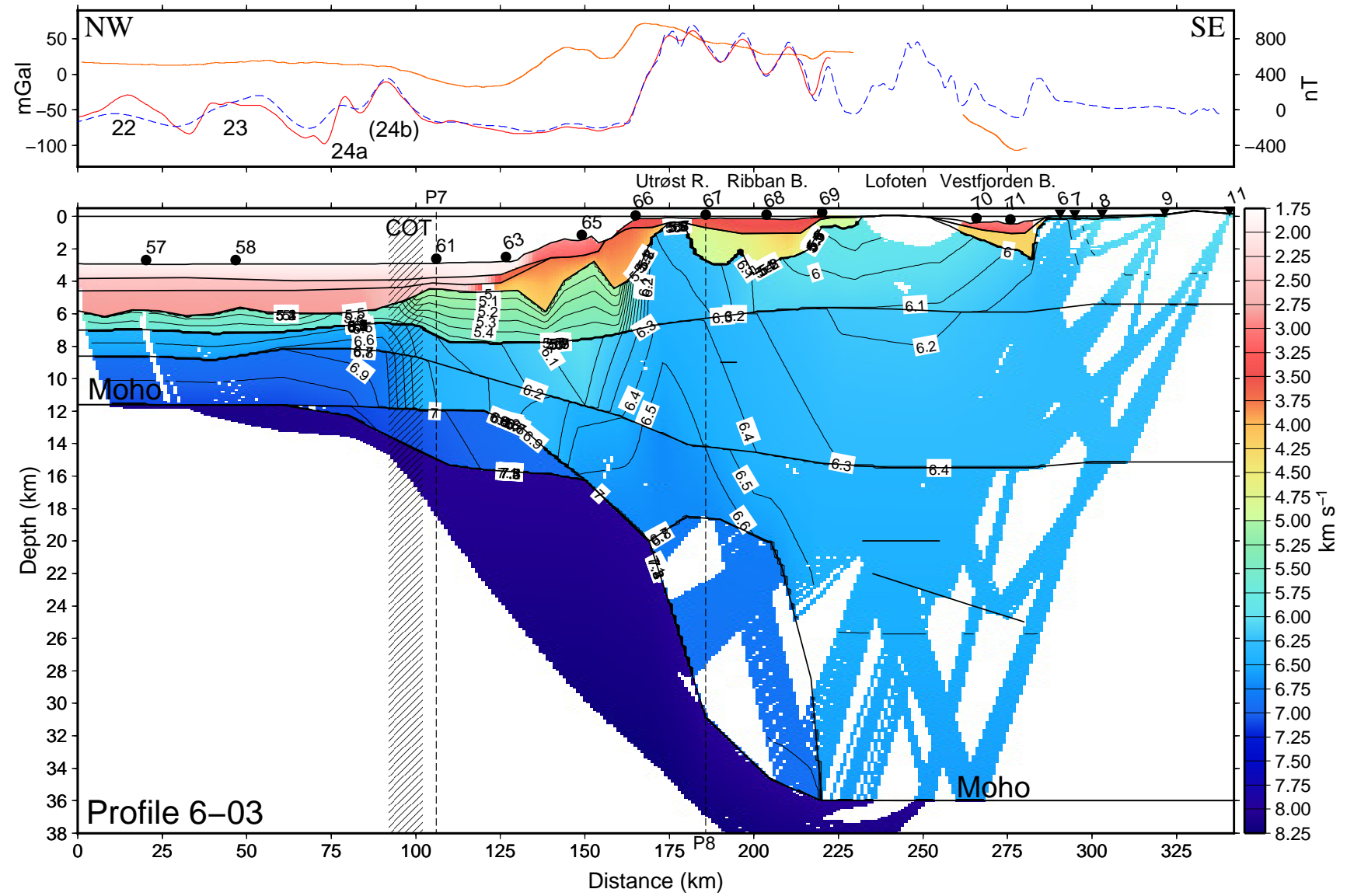

Figure 10: Gridded crustal velocity model of Profile 6-03, showing ray coverage. The OBS/H locations are numbered on the seafloor, and seismometers onshore. Hachures indicate the continent-ocean transition (COT). The magnetic (red solid line) and Free-air gravity (orange solid line) tracks collected along profile are shown above. The dashed blue line is extracted from the magnetic grid of Olesen et al. (2010). 

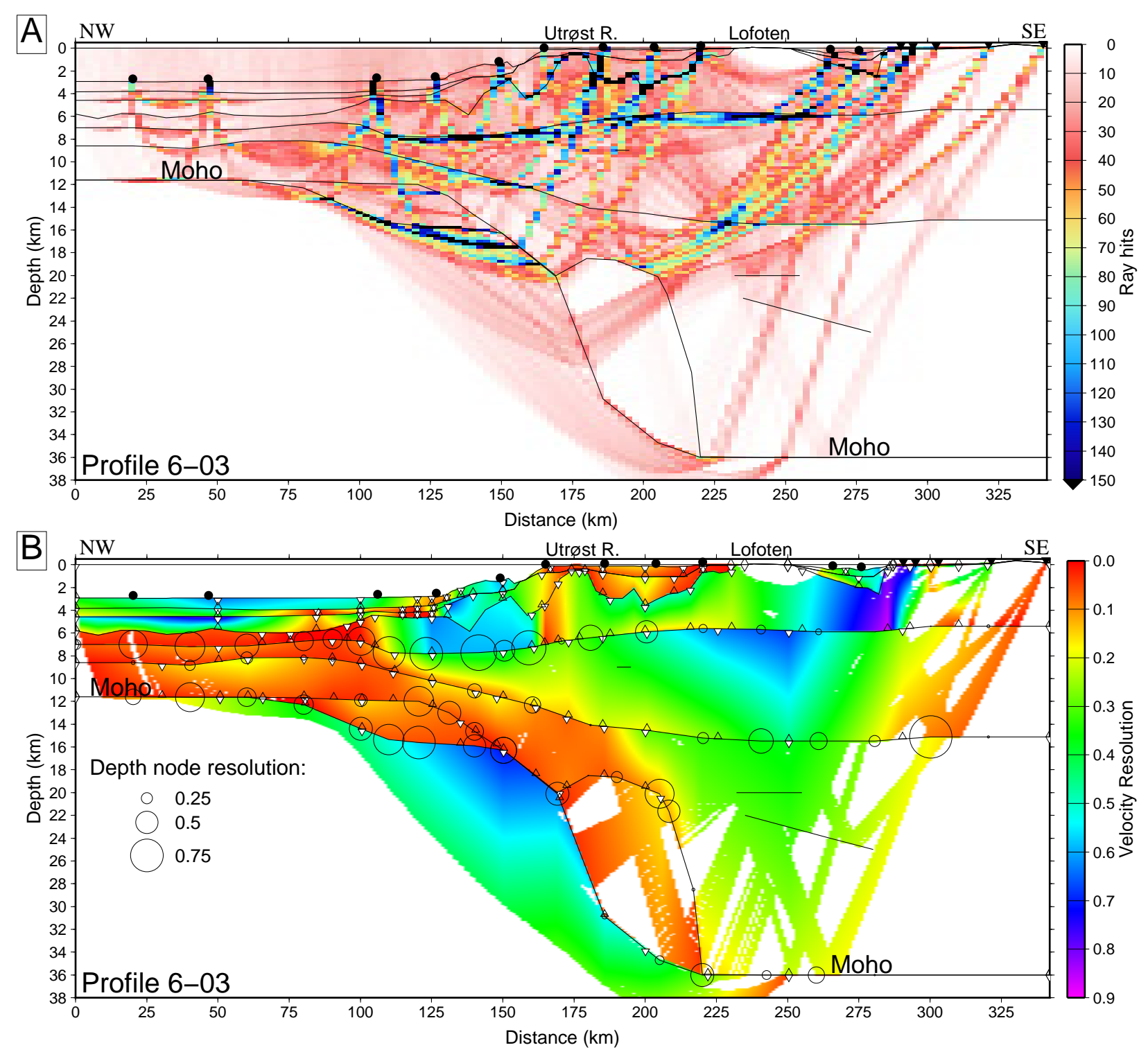

Figure 11: Ray coverage and velocity node resolution. A: Gridded ray coverage of the Profile 6-03 velocity model. The binning is $2.5 \mathrm{~km}$ horizontally and $0.25 \mathrm{~km}$ with depth. B: Gridded resolution parameters of the P-wave velocity nodes obtained from inversion shown by color scale. Node positions at the top of layers are shown by white-filled inverted triangles, while bottom layer node positions are shown by open triangles. Depth node resolution from top of the middle crust to the Moho is shown by circles enclosing them, the larger are better constrained. 


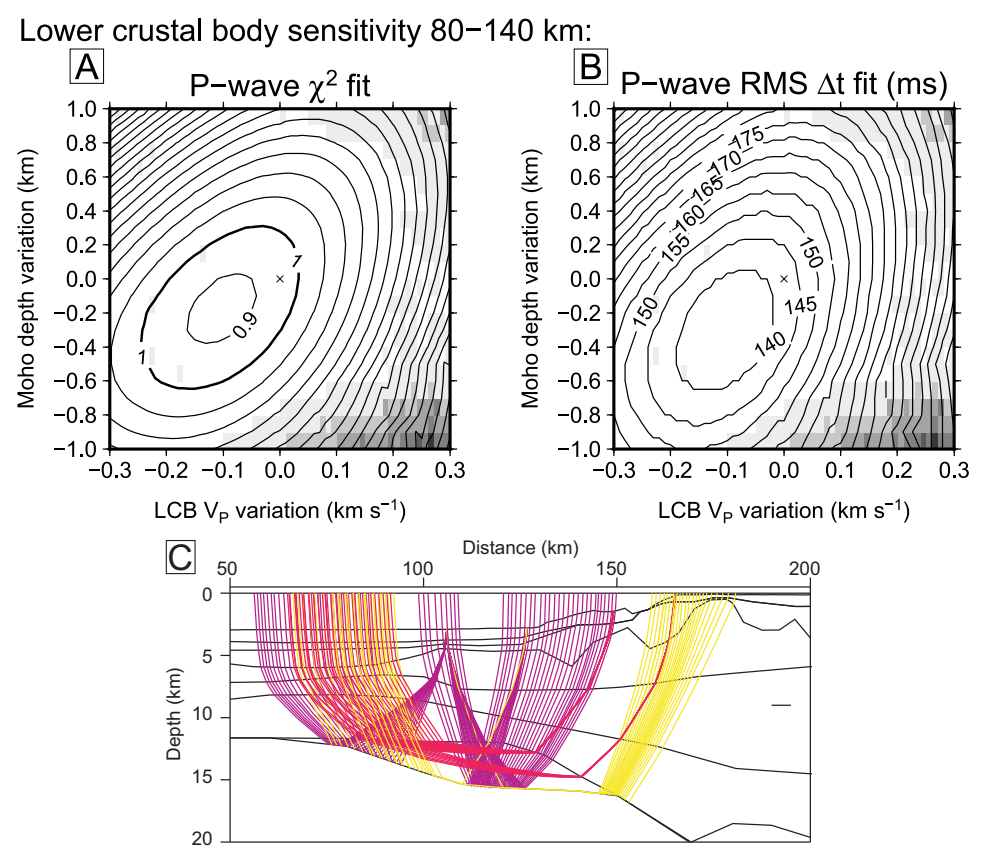

Lower continental crustal sensitivity $90-140 \mathrm{~km}$ :
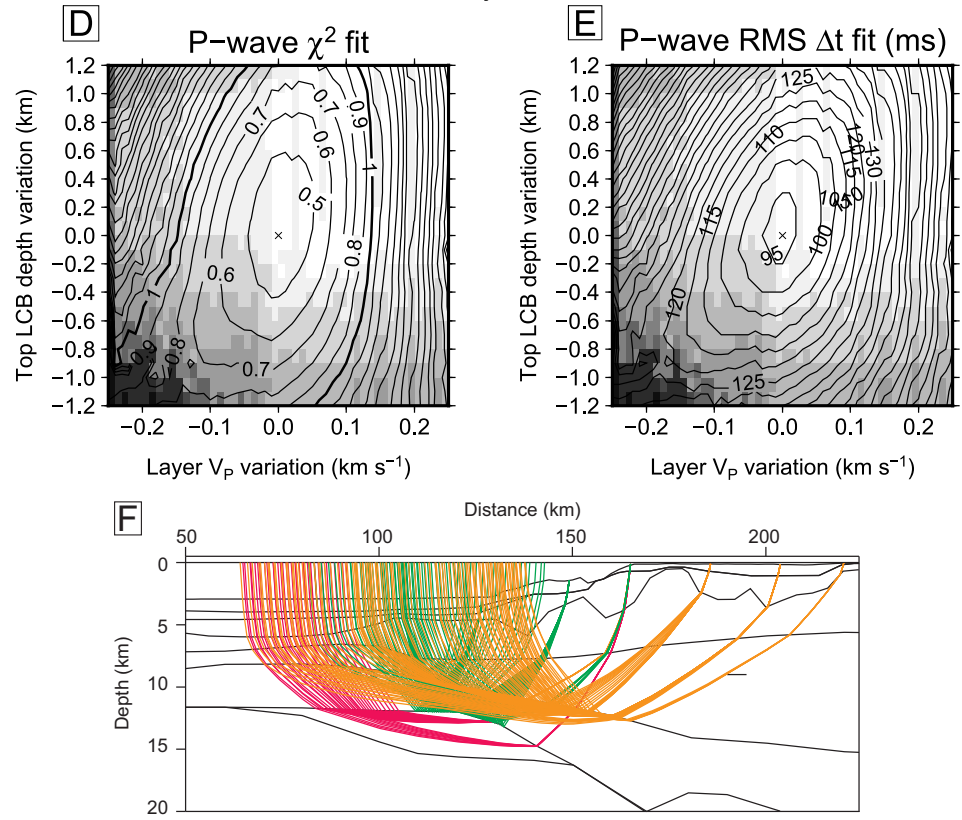

Figure 12: Model sensitivity to layer bottom depth variations versus layer velocity for the outer margin. Deeper gray shading indicates increasing loss of rays. A: $\chi^{2}$ fit for Moho depth variations versus LCB velocity for nodes between 80-140 km in the model, B: corresponding RMS $\Delta \mathrm{t}$ fit in milliseconds (ms), C: $\mathrm{P}_{M} \mathrm{P}, \mathrm{P}_{g 4}$, and $\mathrm{P}_{n}$ phases used in the analysis in A-B. D: $\chi^{2}$ fit for lower continental crust above the LCB versus depth to top of LCB for nodes between 90-140 km, E: corresponding RMS $\Delta$ t fit, F: $\mathrm{P}_{C} \mathrm{P}, \mathrm{P}_{g 3}$, and $\mathrm{P}_{g 4}$ phases used in the analysis in D-E. 

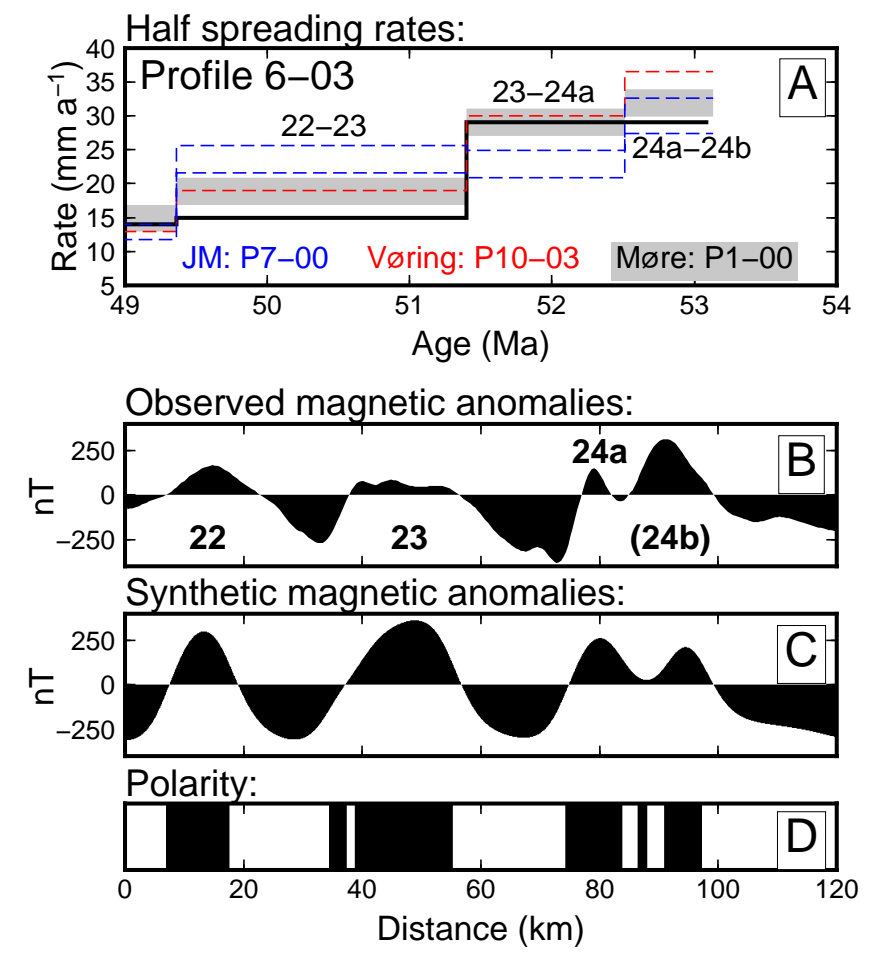

Figure 13: A: Half spreading rates between the center of magnetic anomalies along Profile 6-03, adjusted to spreading direction and plotted against age (solid line) (Cande and Kent, 1995). Gray shading shows the results from the Møre Margin, where the width indicates a $\pm 2 \mathrm{~mm} \mathrm{y}^{-1}$ uncertainty (Breivik et al., 2006). Blue dashed lines show the results from the Jan Mayen micro-continent margin conjugate to the Møre Margin, where minimum and maximum estimates are based on the uncertainty of estimated spreading direction (Breivik et al., 2012). The red dashed line is from the northern edge of the Vøring Plateau (Breivik et al., 2009). B: The observed magnetic anomalies plotted against profile distance, with normal magnetic anomaly identifications annotated in bold. C: Synthetic magnetic anomalies calculated from panel D. D: Geomagnetic polarity model calculated from rates in A based on Cande and Kent (1995), assuming breakup time at $53.1 \mathrm{Ma}$ and a reverse polarity for the adjacent continental crust. 

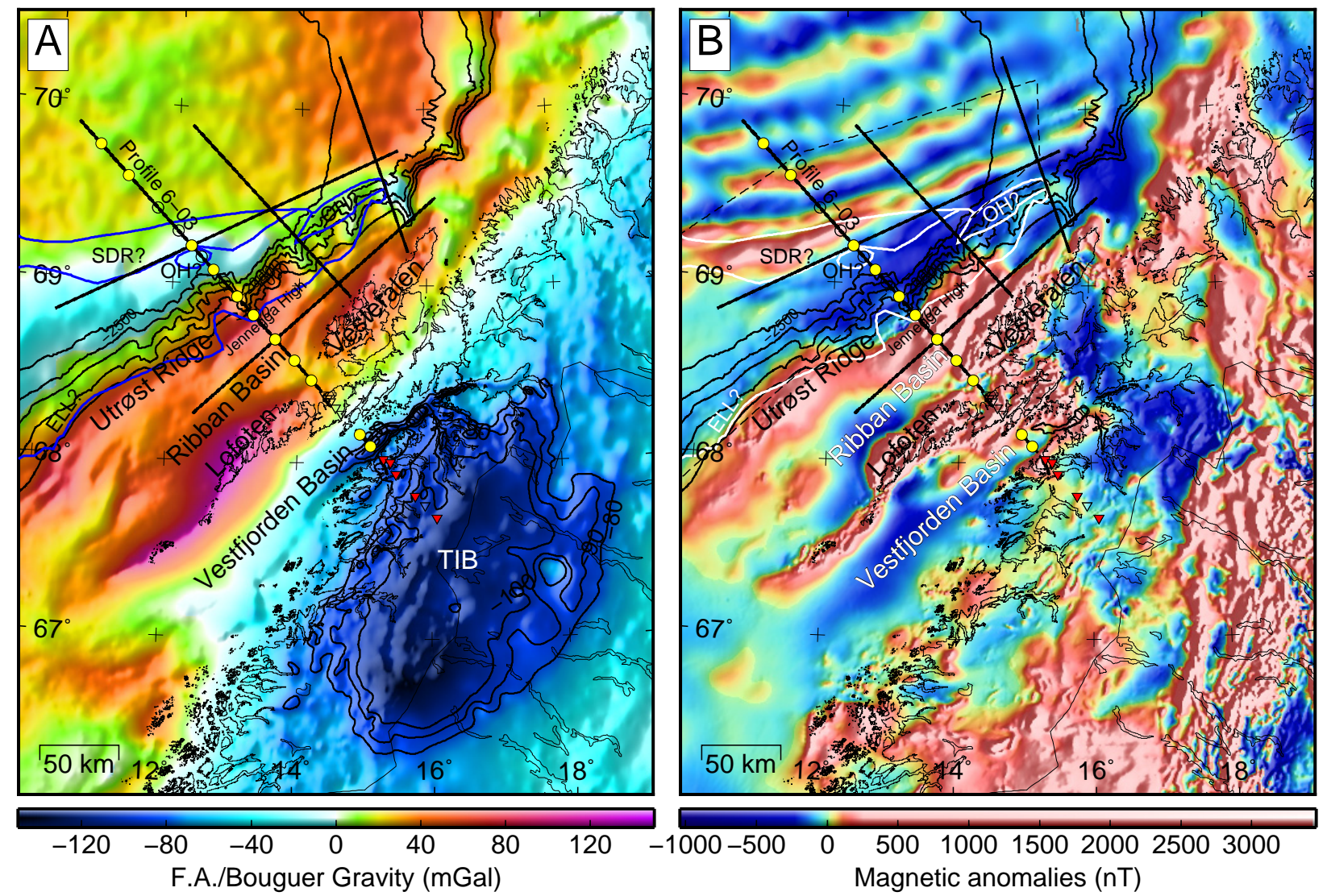

Figure 14: A: Free-air gravity (marine) and Bouguer gravity onshore (Olesen et al., 2010). Onshore contours show gravity values of $-80,-90$, and -100 mGal. B: Regional magnetic anomalies (Olesen et al., 2007, 2010). The new RAS-03 survey area is indicated by the dashed line. A and B: Bathymetric contours at $500 \mathrm{~m}$ intervals are shown on top of both grids. Euromargins 2003 OBS lines are also shown, with OBS positions (yellow-filled circles) and land stations (red-filled, inverted triangles) on Profile 6-03. White lines show magmatic interpretations from Berndt et al. (2001); ELL?: Eastern limit lava?, OH?: Outer volcanic highs?, SDR?: Seaward dipping reflector sequence?, TIB: Trans-Scandinavian Igneous Belt body. Swedish data (CSwedish Geological Survey. 


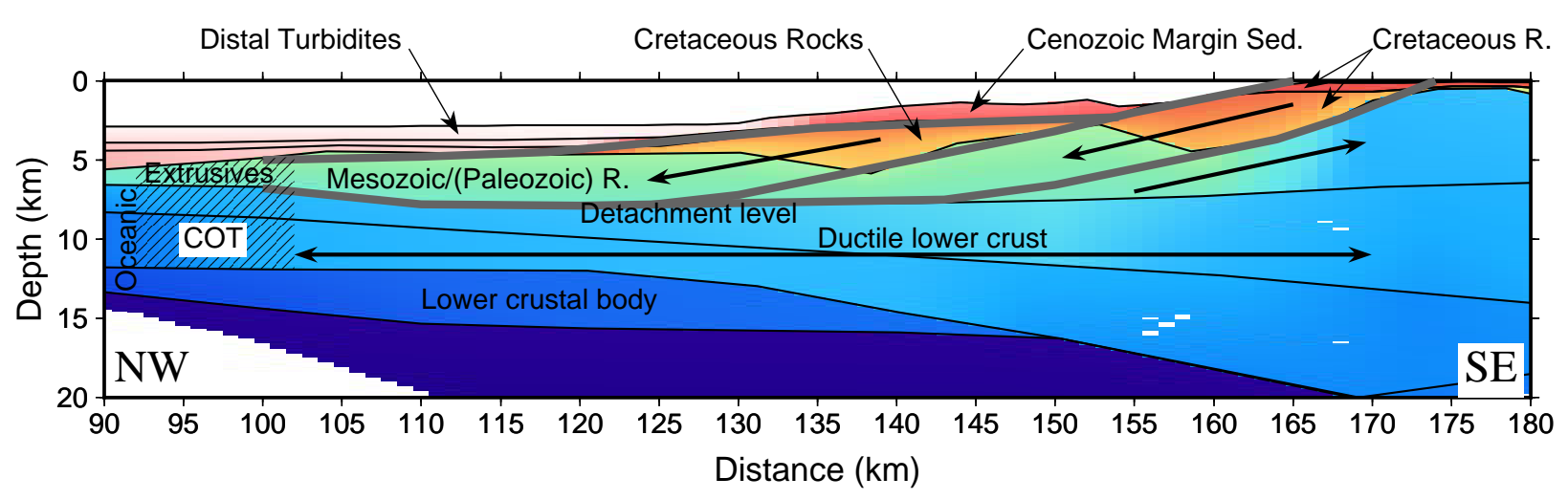

Figure 15: Tectonic model of the outer margin superimposed on the velocity model, with no vertical exaggeration. Gray bands indicate low-angle detachment faults, and the thick arrows show relative direction of movement. Detachments are interpreted to sole out on the top of the ductile lover crust. The hanging wall block is missing from the upper detachment, presumably left on the Northeast Greenland margin, exposing the lower sedimentary layer at the outer margin. 